\title{
The Relation between Economic Development and International Trade: A Comparative Analysis of East Asian and Southeast Asian Economies
}

\author{
Rainer Doppler
}

\begin{abstract}
The impressive economic development of East Asian and Southeast Asian countries, like China, Japan, South Korea, or Singapore, is often described as the 'Asian economic miracle'. The transition from a less developed economy to an industrialised country and successful integration into the global economy within a relatively short period of time are characteristics of the economic development process. Academic research is dominated by a general agreement on the causal relationship between economic development and international trade. The research goal of this paper is to analyse the impact of the level of economic development on the degree of international trade in the economies of China, Japan, South Korea, Singapore and Thailand. The applied research model does not follow the traditional research mainstream but rather introduces relative shares of GDP-related industrial output and of manufactures exports by adopting national as well as international perspectives instead. Descriptive trend analysis, correlation analysis and regression analysis are conducted in order to test the hypotheses. The results do not support conventional academic wisdom. A statistically reasonable causality between the level of economic development, in terms of relative industrial output, and the degree of international trade, in terms of relative industrial exports, could not be confirmed.
\end{abstract}

Keywords: Economic Development, International Trade, China, Japan, South Korea, Singapore, Thailand

Doppler, Rainer. "The Relation between Economic Development and International Trade: A Comparative Analysis of East Asian and Southeast Asian Economies.” In Vienna Journal of East Asian Studies, Volume 7, eds. Rudiger Frank, Ina Hein, Lukas Pokorny, and Agnes Schick-Chen. Vienna: Praesens Verlag, 2015, pp. 67-101. https://doi.org/10.2478/vjeas-2015-0003 


\section{Introduction}

'If you understand everything, you must be misinformed'. (Japanese Proverb)

The exchange of goods between people all around the world has been playing an essential role throughout the history of humanity. Economic exchange relations between nations have been taking place since ancient times, and all kind of goods have been traded throughout a globalised world. Over the period of the last few centuries, especially since the twentieth century, steadily growing international trade relations have become an important key element in sustaining the development of a prosperous economy and wealthy society. Between 1960 and 2010, World Trade as a percentage of World Gross Domestic Product grew from $24.2 \%$ to $56.1 \%$ (see Figure 1).

Figure 1 Development of World Trade in per cent of World GDP between 1960 and 2010

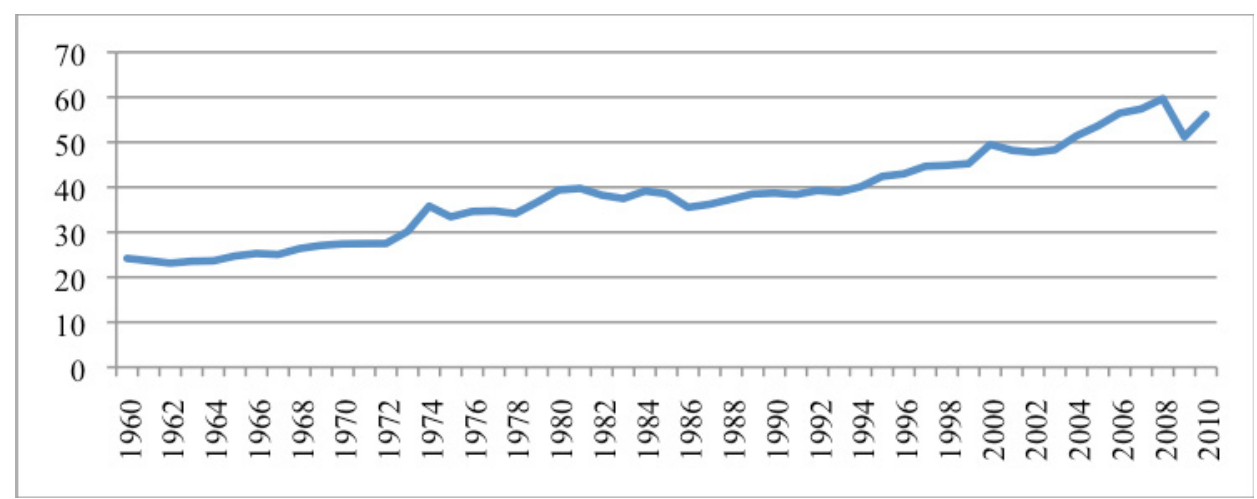

Source: World Bank 2013

Today, the East Asian and Southeast Asian Area can be seen as being among the most important regions in terms of their shares in the global GDP and International Trade. Due to this fact, China, Japan, South Korea, Hong Kong, Singapore, and Taiwan are among the leading trading economies worldwide (Table 1). 
Table 1: Top 20 Exports and Imports Economies 2011

\begin{tabular}{|l|r|c|c|}
\hline Exports 2011 & \multicolumn{1}{|c|}{ US Dollar } & \% & acc. \\
\hline World & $\mathbf{1 8 . 2 1 7 . 0 0 0 . 0 0 0 . 0 0 0}$ & & \\
\hline China & 1.898 .600 .000 .000 & 10.4 & 10.4 \\
\hline United States & 1.480 .645 .800 .000 & 8.1 & 18.5 \\
\hline Germany & 1.473 .889 .132 .800 & 8.1 & 26.6 \\
\hline Japan & 822.673 .613 .150 & 4.5 & 31.2 \\
\hline Netherlands & 660.379 .416 .000 & 3.6 & 34.8 \\
\hline France & 597.058 .310 .400 & 3.3 & 38.1 \\
\hline South Korea & 555.213 .655 .000 & 3.0 & 41.1 \\
\hline Italy & 523.000 .569 .600 & 2.9 & 44.0 \\
\hline Russia & 521.968 .000 .000 & 2.9 & 46.8 \\
\hline Belgium & 476.271 .825 .600 & 2.6 & 49.5 \\
\hline UK & 473.322 .873 .600 & 2.6 & 52.1 \\
\hline Hong Kong & 455.663 .383 .000 & 2.5 & 54.6 \\
\hline Canada & 452.166 .838 .272 & 2.5 & 57.0 \\
\hline Singapore & 409.503 .911 .484 & 2.2 & 59.3 \\
\hline Saudi Arabia & 364.500 .000 .000 & 2.0 & 61.3 \\
\hline Mexico & 349.675 .857 .000 & 1.9 & 63.2 \\
\hline Taiwan & 308.257 .300 .000 & 1.7 & 64.9 \\
\hline Spain & 297.418 .200 .000 & 1.6 & 66.5 \\
\hline India & 296.556 .460 .000 & 1.6 & 68.2 \\
\hline UAE & 285.000 .000 .000 & 1.6 & 69.7 \\
\hline
\end{tabular}

\begin{tabular}{|l|r|c|c|}
\hline Imports 2011 & \multicolumn{1}{|c|}{ US Dollar } & \% & acc. \\
\hline World & $\mathbf{1 8 . 3 8 1 . 0 0 0 . 0 0 0 . 0 0 0}$ & & \\
\hline United States & 2.265 .421 .300 .000 & 12.3 & 12.3 \\
\hline China & 1.743 .458 .000 .000 & 9.5 & 21.8 \\
\hline Germany & 1.253 .951 .323 .200 & 6.8 & 28.6 \\
\hline Japan & 854.267 .437 .427 & 4.6 & 33.3 \\
\hline France & 714.733 .675 .200 & 3.9 & 37.2 \\
\hline UK & 636.296 .284 .800 & 3.5 & 40.6 \\
\hline Netherlands & 597.233 .702 .400 & 3.2 & 43.9 \\
\hline Italy & 556.873 .080 .000 & 3.0 & 46.9 \\
\hline South Korea & 524.413 .090 .000 & 2.9 & 49.8 \\
\hline Hong Kong & 511.293 .336 .000 & 2.8 & 52.5 \\
\hline Canada & 462.435 .000 .000 & 2.5 & 55.1 \\
\hline Belgium & 460.762 .440 .000 & 2.5 & 57.6 \\
\hline India & 450.956 .950 .000 & 2.5 & 60.0 \\
\hline Singapore & 365.770 .792 .235 & 2.0 & 62.0 \\
\hline Spain & 362.109 .033 .600 & 2.0 & 64.0 \\
\hline Mexico & 361.067 .429 .000 & 2.0 & 65.9 \\
\hline Russia & 323.208 .000 .000 & 1.8 & 67.7 \\
\hline Taiwan & 281.437 .500 .000 & 1.5 & 69.2 \\
\hline Australia & 243.699 .000 .000 & 1.3 & 70.6 \\
\hline Turkey & 240.834 .392 .285 & 1.3 & 71.9 \\
\hline
\end{tabular}

Source: World Trade Organisation 2013; acc. $=$ accumulated; UAE $=$ United Arab Emirates

Table 2 underlines the importance of the ASEAN+3 Area to global trade in general. In 2011, the East Asian economies of China, Japan, South Korea, and Hong Kong were responsible for $20.5 \%$ of exports and for $19.8 \%$ of imports. The entire ASEAN +3 area contributed an exports share of $27.3 \%$ and an imports share of $26 \%$ to total international trade.

There is a general consensus that a country benefits from opening its economy to international trade. The advantages of free trade are multifaceted and include positive effects on economic development and growth; creation of jobs; increased income and standards of living; national wealth; choice from a wide range of products and goods; research and development of innovations; global diffusion of knowledge and technology, and political stability and peace between nations (World Trade Organisation 2008). 
Table 2: ASEAN+3 Exports and Imports 2011

\begin{tabular}{|l|r|l|l|}
\hline Exports & \multicolumn{1}{|l|}{ US Dollar } & \% & acc. \\
\hline World & $\mathbf{1 8 . 2 1 7 . 0 0 0 . 0 0 0 . 0 0 0}$ & & \\
\hline China & 1.898 .600 .000 .000 & 10.4 & 10.4 \\
\hline Japan & 822.673 .613 .150 & 4.5 & 14.9 \\
\hline South Korea & 555.213 .655 .000 & 3.0 & 18.0 \\
\hline Hong Kong & 455.663 .383 .000 & 2.5 & 20.5 \\
\hline Singapore & 409.503 .911 .484 & 2.2 & 22.7 \\
\hline Thailand & 228.821 .780 .000 & 1.3 & 24.0 \\
\hline Malaysia & 226.989 .557 .622 & 1.2 & 25.2 \\
\hline Indonesia & 201.472 .259 .000 & 1.1 & 26.3 \\
\hline Vietnam & 96.905 .673 .959 & 0.5 & 26.9 \\
\hline Philippines & 48.042 .000 .000 & 0.3 & 27.1 \\
\hline Brunei & 12.250 .000 .000 & 0.1 & 27.2 \\
\hline Myanmar & 10.500 .000 .000 & 0.1 & 27.3 \\
\hline Cambodia & 6.950 .000 .000 & 0.04 & 27.3 \\
\hline Laos & 2.400 .000 .000 & 0.01 & 27.3 \\
\hline
\end{tabular}

\begin{tabular}{|l|r|c|c|}
\hline Imports 2011 & US Dollar & $\%$ & acc. \\
\hline World & $\mathbf{1 8 . 3 8 1 . 0 0 0 . 0 0 0 . 0 0 0}$ & & \\
\hline China & 1.743 .458 .000 .000 & 9.5 & 9.5 \\
\hline Japan & 854.267 .437 .427 & 4.6 & 14.1 \\
\hline South Korea & 524.413 .090 .000 & 2.9 & 17.0 \\
\hline Hong Kong & 511.293 .336 .000 & 2.8 & 19.8 \\
\hline Singapore & 365.770 .792 .235 & 2.0 & 21.8 \\
\hline Thailand & 228.498 .070 .000 & 1.2 & 23.0 \\
\hline Malaysia & 187.660 .739 .018 & 1.0 & 24.0 \\
\hline Indonesia & 176.354 .558 .000 & 1.0 & 25.0 \\
\hline Vietnam & 106.749 .853 .535 & 0.6 & 25.6 \\
\hline Philippines & 64.010 .000 .000 & 0.3 & 25.9 \\
\hline Cambodia & 9.300 .000 .000 & 0.1 & 26.0 \\
\hline Myanmar & 7.200 .000 .000 & 0.04 & 26.0 \\
\hline Brunei & 3.250 .000 .000 & 0.02 & 26.0 \\
\hline Laos & 2.650 .000 .000 & 0.01 & 26.0 \\
\hline
\end{tabular}

Source: World Trade Organisation 2013; acc. = accumulated

Over the last few decades some of the East Asian and Southeast Asian economies have achieved impressive economic development by participating in the world economy. Countries like China, Japan, South Korea, Taiwan or Singapore have thus benefited from this strategy, which is commonly referred to as the 'Asian Miracle'. Comprehensive academic research has made tremendous efforts to analyse and to explain the reasons for this performance, not only in order to understand the causal relationships and dynamics of this economic development process, but also to provide practical advice which informs economic policy measures.

The research goal of the underlying study was to make a contribution to the general understanding of the causal relationships between the level of economic development and the level of international trade. Therefore, the following research question was formulated:

What is the impact of the degree of economic development of an economy on the intensity of its international trade?

\section{Theoretical Framework}

International trade relations primarily comprise goods and services which are exchanged transnationally by at least two trading partners from different countries. In 2011 the share of traded goods within total trade activities was $80.7 \%$. Services account for only $19.3 \%$ of total trade activities (World Trade Organisation 2013). 
Furthermore, by taking a sectoral perspective on trade relations it is possible to differentiate between inter-industry and intra-industry trade. In the former case goods and services were exchanged between trading partners from different industries, in the latter case the trading partners refer to the same industry. Within intraindustry trade it is possible to distinguish between horizontal intra-industry trade, if exchanged goods and services are produced with a given input factor combination at the same quality levels and price levels, and vertical intra-industry trade, for traded goods and services with different quality levels and different prices. The majority of international trade relations cover intra-industry traded products. There are many reasons for international trade. Most of them cannot be treated as isolated determinants for export and import relations, but rather comprise different interdependent factors, like differences in the availability of input factors, differences in factor prices and production cost functions, differences in demand preferences, and differences in the utilisation of production capacities (Chacholiades 1978: 7; Farmer and Wendner 1999: 191; Siebert 2000: 171; Riveira-Batiz and Oliva 2003: 39; Rübel 2004: 7; Eibner 2006: 22; Bender 2007: 478-484; Krugman 2009: 166-199).

The economic policy of a country has a sustaining impact on the economic development as well as on the international trade relations of an economy. In accordance with its economic objectives, a national government determines the economy of a country and its international trade relations through the implementation of legal frameworks and different regulatory measures. In this way, the state can interfere in the national economy to a greater or lesser extent. The scope of possible actions ranges from a minimum of state influence through a laissez-faire policy, to a centrally planned command economy with dominant state influence. Regarding international trade relations, the government of a country can promote or limit and prohibit exports and imports of specific products through protectionist measures. State protectionism is pursued for manifold reasons, for example to develop national industries and provide protection from foreign competition, to pursue selfsufficiency with regard to specific goods and services, to secure jobs or to stimulate national demand for national products (Rübel 2004: 183; Eibner 2006: 174; Bender 2007: 517; Krugman 2009: 252).

The term 'Asian Miracle' has been introduced to describe and to understand the process of the impressive economic development of several East Asian and Southeast Asian economies within only a few decades. The rise of the Asian Miracle States is closely related to the concept of the Developmental State. The interference of national governments into their domestic economies by implementing legal frameworks in order to influence and to control the execution of political goals is common economic policy. The main characteristic of the Asian Developmental State is the successful combination of a free market economy and the influencing visible hand of the state (Johnson 1983; Park 1990; Huff 1995; Stiglitz 1996: 151; Pempel 1999; Haas and Neumair 2006: 321; Akkemik 2009: 10). 
Despite the postulated advantages of economic integration into the global economy on the one hand, there are also risks of an interconnected economic network for each individual country on the other hand. The case of economic crisis with a starting point in a single country can result in economic epidemics and effect considerable impact on the economic stability and economic development of other nations. The Asian financial crisis of $1997 / 1998$, for example, can be classified as a crisis with far reaching effects on national economies, not only for countries in the Asian region but also for the world economy (Ichimura et al. 1998: 20; Dieter 1998: 13; Letiche 1998: 181; Green and Campos 2001: 310; Götte 2012).

The national economy of a country is determined by all the economic activities of its economic subjects as individuals, households, and private and public companies with reference to the production, distribution, and consumption of goods and services within national borders. One of the key indicators on the highest aggregate level to measure the total economy output is the Gross Domestic Product (GDP). In order to explain the economic structure from the perspective of the production side, GDP is commonly divided into the primary sector, the industrial sector, and the services sector. The economy of modern industrialised nations is usually characterised by a low share of the primary sector and a relatively high share of a dominant services sector. Nevertheless, the industrial sector of developed countries can also contribute relatively high shares to the GDP. The wealth of an individual nation is often measured by GDP per capita, assuming that the population benefits from an increasing economic output and economic development. The World Bank divides economies depending on their level of economic development by applying Gross National Product (GNP) per capita, or rather Gross National Income (GNI) per capita. By this approach each nation can be classified into at least the categories Low-income country (LIC), Middle-income country (MIC) or High-income country (HIC) (World Bank 2013).

The process of economic development is complex and differs from country to country. Theories of economic development as well as economic growth theories analyse the differentiated relations between determining factors and their impacts on economic progress. The application and reduction of a sophisticated economic reality to simple theoretical models limited by generalizing assumptions provides a basic understanding of and valuable insights into economic development processes, but also room for controversial discussions and criticism. Although the academic literature offers a comprehensive set of different economic theories, there is no generally accepted classification system in the field of development economics.

Depending on the existence of international economic relations, economies can be divided into closed and open systems. The latter classification applies to most countries in the world. The degree of international trade relations of an economy is connected directly to the structure of the national production output and the level of economic development. The academic field of international economics deals with 
the analysis and explanation of diversified matters of economic relations between countries and economic exchange processes related to the global economy. The analysis of international economics-related subjects is characterised by the application of theoretical approaches from different sub-fields within economics like microeconomics, macroeconomics, economic policy, and developmental economics (Linder 1961: 11; Breuss 1997: 1; Siebert 2000: 1; Rübel 2004: 7; Eibner 2006: 17; Bender 2007: 477; Krugman 2012: 33).

Due to the diversity within the theoretical approaches analysing and explaining the process of economic development of nations as well as the reasons and causalities of international trade relations between economies, a holistic perspective taking into account accurately the close interdependence between the relevant determinants of development and trade is recommended at this point. On the one hand, the majority of theories of economic development focus on the fundamental dynamics of specific production factors like land, labour, capital and technological progress, to economic growth and structural development. Dating back to the eighteenth and nineteenth centuries, the Classical Theorists, like Smith, Malthus, and Marx already based their analysis on these key factors, followed by Linear-Stage Growth Theories, like Rostow's Take-off Model, Structural Change Theories, like Fourastié's Three Sector Hypothesis, Lewis's Dual Sector Model and Adelman's Model of Agricultural Demand-led Industrialisation, Neo-Classical Growth Models, like the Harrod-Domar Model and the Solow Growth Model, as well as Balanced Growth Theories, like Rosenstein-Rodan's Theory of the Big Push (Harrod 1939; Rosenstein-Rodan 1943; Domar 1946; Rostow 1956; Solow 1956; Fourastié 1969: 238; Adelman 1975; Adelman 1984; Rostow 1990: 4; Hess and Ross 1997; Todaro and Smith 2003; Cypher and Dietz 2004; Nafziger 2012).

On the other hand, trade theories focus on the analysis of the exchange of goods and services between economic subjects. Since the seventeenth century the economic policy of Mercantilism and Classical Theorists, like Smith, Mill, List, and Ricardo, advocated the importance of free trade and the maximising of trade surplus. Ricardo's Theory of Comparative Advantage can be classified as one of the fundaments of international trade analysis up to modern times. The Neo-Classical Trade Theories, like Heckscher's and Ohlin's Factor Proportions Theory, the Stolper Samuelson Theorem, the Rybczynski Theorem, the Factor Price Equalisation and the Specific Factors Model, based their analysis on the principles of comparative advantages and further developed Ricardo's approach by introducing additional determinants into the academic discussion (Stolper and Samuelson 1941; Samuelson 1948; Rybczynski 1955; Chipman 1965: 482; Chacholiades 1978: 13; Johns 1985: 155-169; Markusen et al. 1995: 85-119; Albaum 2001: 52; Rivera-Batiz and Oliva 2003: 3-4; Eibner 2006: 80; Bender 2007: 485; Marrewijk 2007: 96-115; Zhang 2008: 46; Krugman et al. 2012: 81-128). 
With reference to the underlying research question, the following theoretical approaches are indicated as demonstrative examples for applying a more holistic perspective in terms of analysing the relation between economic development and international trade. The indicated theories underline explicitly the dependence of trade relations, defined by the industry sector-related category of traded products, on the level of economic progress, measured in terms of GDP-related contributions of industrial sectors to the national economy. In other words, the class of traded products depends on the level of economic development of a nation.

Endogenous Growth Models emphasise, like neoclassical growth theories, the importance of technological progress as the key driving factor for economic growth. In contrast to the neoclassical growth theories, which postulate long-term growth determined by external factors, endogenous growth theories underline the impact of internal factors, which can be explained within an economic growth model. One of the main differences between developing countries and industrialised nations is an existing technology gap caused by limited access to knowledge and technology. In order to stimulate economic growth, public policy should therefore aim at investments in the research and development of innovative technology, the accumulation of qualified human resources as well as in knowledge-intensive industries. Developing countries with limited capabilities to innovate advanced technologies should focus on the development of human capital and on integration into the global economy by opening their countries to international trade and to foreign direct investments (Romer 1986; Grossmann and Helpman 1990; Romer 1990; Hess and Ross 1997: 109; Todaro and Smith 2003: 147; Lin 2004; Nafziger 2012: 151).

The Gravity Model of Trade is inspired by the Isaac Newton's law of universal gravitation which basically argues that the attraction of two masses, is a function of their masses and distance. Simply put, according to this theory the gravitational pull between two objects grows with the increasing size of their masses and the decreasing of the distance between them. In terms of international economics, the larger the economic size of two countries in terms of national production output, like GDP, and the shorter the distance between these two countries, the larger the bilateral international trade relations, in terms of exports and imports, between these two countries. The determining indictors of the economic gravity model of international trade are GDP, which also reflects the level of economic development, and the distance factor. Distance refers not only to the geographical distance and the existence of common borders, but can also be understood in terms of membership in the same trade zones, common history, culture or language, and other variables. In the context of this paper, the economic distance described by the level of economic development, by similarities in the sector-related structure of the economy, or by similarities in national supply and demand dynamics shall be emphasised. The key findings postulate that countries with similarities in their GDP-related economic structures and their national demand structure tend significantly to sustain trade 
exchanges, in particular to trade in industrial products and high tech products (Linder 1961: 107; Tinbergen and Bos 1962: 93; Patel 1964: 126; Frankel and Romer 1999; Siebert 2000: 88; Filippini and Molini 2003: 710; Yamarik and Ghosh 2005: 83; Kien 2009: 266; Krugman et al. 2012: 42).

Following the tradition of the Heckscher-Ohlin model, Linder postulated a Demand-based Theory of International Trade. In contrast to supply based theories which emphasise differences in the factor endowment of economies as the key driver determining trade between countries, Linder theorised that trade between two countries depends on the degree of similarities in the demand structure of these two countries. In the ideal case of exactly the same demand structure, the exported and imported goods of these two countries are exactly equal. For a more detailed specification, Linder differentiates between the trade in primary goods and in manufactured goods. Linder's assumptions include primarily the latter ones. The degree of similarity in demand structure is measured by per capita income, expressing the economic progress of a nation, assuming that the level of average income is the key driver of the demand structure. The national product range of manufactures in an economy depends on a sufficient domestic demand for manufactures. With increasing market saturation, entrepreneurs will evaluate potential export markets for their products and focus on economies with similar levels of income and demand structures (Linder 1961: 94; Bhagwati 1964: 26; Johns 1985: 205; Markusen et al. 1995: 202; Bender 2007: 508).

In analogy to the invention and diffusion of technologies and products, Vernon introduced the Product Cycle Theory of Trade to analyse and explain international trade patterns. For most goods, technology is a determining factor in the production and market diffusion process. Generally the life cycle of a technology or product can be described by the stages of innovation, introduction and growth, maturity and saturation, and decline. At the beginning of the cycle, capital- and knowledgeintensive technologies and products are usually innovated and introduced in industrialised countries. Based on strong domestic markets, developed countries take the role of exporters of innovative products. The increasing market success and standardisation of products accompanied by international knowledge transfer result in international competitive market situations with an increasing number of suppliers and declining prices. Finally, the product production has to be relocated to low-wage economies, and thus to less developed countries. The industrialised nations still focus on the invention of new innovative technologies and products and the life cycle starts anew. The product cycle theory can be used to explain the development of international trade directions for many products in different industries and the market-forced mobility of production capacities from industrialised economies to developing countries caused by global competition, experience curve effects, economies of scale and decline in prices (Vernon 1966: 190; Evans et al. 1988; Mar- 
kusen et al. 1995: 207; Münt 1996: 3; Siebert 2000: 97; Albaum 2001: 52; RiveraBatiz and Oliva 2003: 188; Bender 2007: 510).

In the context of the industrial policy of the developmental state regarding the economic development process and the role of international trade to the economic development of a country, the Wild Geese Flying Pattern Model of Akamatsu can be stated as an East Asian model for a state driven economic development approach. In this model, a strong developmental state promotes the economic development of selected national key industries. The economic development process passes four stages whereby international trade and the realisation of national comparative advantages play a crucial role. The international trade of less developed countries is limited to the export of primary goods and the import of consumer products from developed countries. In this stage, developing countries benefit from comparative advantages resulting from trade with countries to which they are geographically distant. In the second stage, the developing country starts with the production of consumer products for the domestic markets, which in turn increases the national purchasing power and capital accumulation. The demand for capital-intensive products determines imports. In this phase, the state plays an important and active role by applying specific measures of industrial policy. In the third stage, with increasing growth of the national consumer products industry and the development of production capacities, the country exports the national surplus of consumer products to less developed neighbour countries and imports primary goods in return. Moreover, the country starts to produce capital-intensive products in order to meet the demand of the domestic market. In the fourth stage, the country finally exports the capital-intensive products. Akamatsu postulates a sequential process for the development of the capital-intensive sector: import orientation, domestic market production, and export orientation determined by the transition of the production from consumer products to capital-intensive products. One of the essential features of this model is the role of the state not only in promoting a state-led development of selected sunrise industries and in achieving international competitiveness, but also in positioning the sunrise industries as economic accelerators for other industries (Akamatsu 1961: 205; Akamatsu 1962; Adams and Shachmurove 1997; Kojima 2000: 377; Manzenreiter 2007: 100).

\section{Analysis}

\section{Research Model}

In order to answer the research question 'What is the impact of the level of economic development of an economy on its international trade?' the following basic research model is introduced: 
Figure 2 Research Model indicating causal relations between GDP-related and Exports-related aggregates
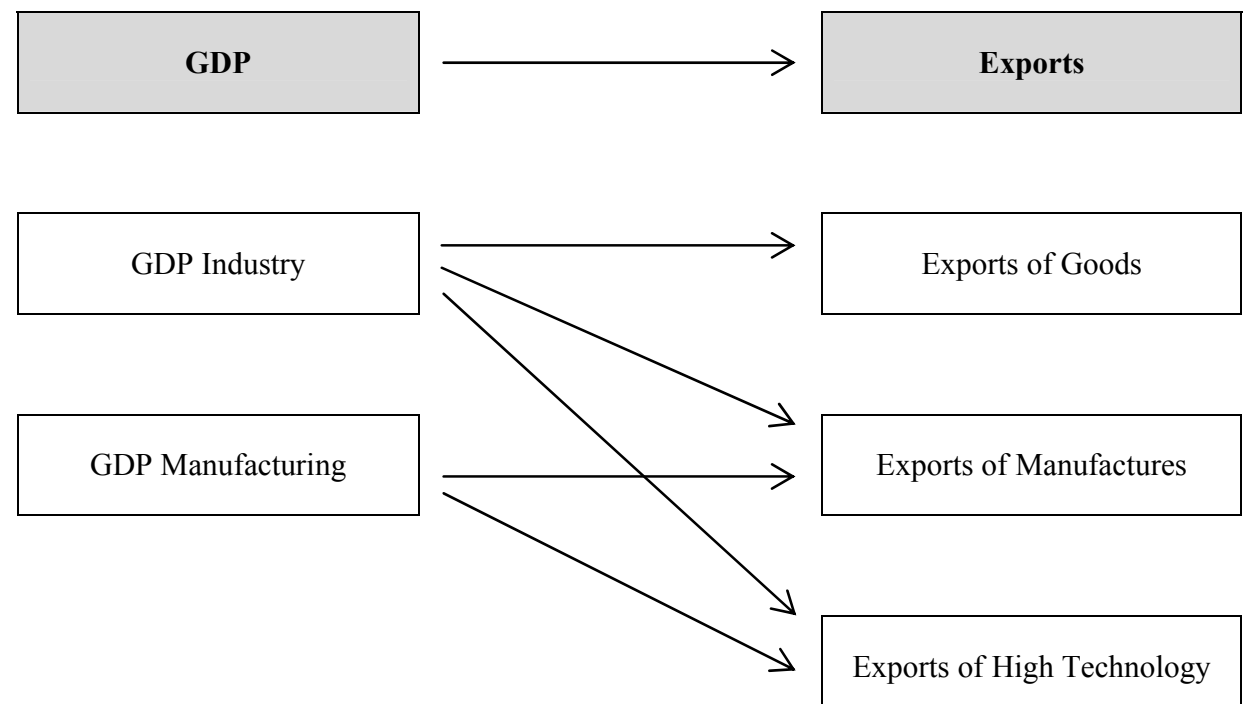

This research model postulates a causal relationship between the level of economic development, in terms of GDP-related aggregates, and the level of international trade, in terms of Exports-related aggregates. In contrast to export-led trade theories, which describe GDP growth by increasing levels of international trade, or rather of exports, the proposed research model implies the hypothetical cause-effect relationship as follows:

An increase (decrease) of industry related GDP aggregates leads to an increase (decrease) of the relevant industry related Exports aggregates.

This general approach was concretised by the following assumptions:

1. The research focus is on the industry sector and relevant products, as the majority of traded products are goods.

2. The level of international trade relations of an economy depends on the level of economic development, in the sense that less developed countries usually produce and trade products from the primary sector, but produce and trade less industrial products. This assumption underlines the fact that the secondary industrial sector has to be developed economically up to a minimum extent whereby sufficient levels of industrial output results in sustaining international trade, or rather exports of manufactures. 
3. The level of economic development can be measured by the individual shares of the GDP sectors contributing to the total GDP of an economy. A characteristic feature of highly industrialised countries is a GDP dominant tertiary sector. In contrast, developing countries are characterised by relatively high GDP shares of the primary sector. In the framework of the underlying research approach, instead of absolute figures the relative shares of sector-related GDP and Exports are used for hypotheses testing. This procedure overcomes two limitations when considering absolute numbers. First, by integrating relative numbers into the research model, the national levels of economic development and export activities as well as the sectoral contribution and sector-related importance in relation to the total economic output are considered in a more appropriate way. Second, by focusing on relative shares, biases caused by differences between countries in terms of size in absolute numbers are eliminated and the comparison of countries is more accurate.

4. Finally, the individual levels of economic integration of different countries into the global economy have been considered by integrating national and international perspectives with reference to the relevant sectoral shares.

Since no study has been found during the course of the literature review which accompanied the research approach presented here, this approach can be considered an innovation.

\section{Variables and Hypotheses}

As a basis for the deduction of the variables, the following World Bank's 'World Development Indicators' were used (World Bank 2013):

\section{GDP (current US\$):}

GDP at purchaser's prices is the sum of gross value added by all resident producers in the economy plus any product taxes and minus any subsidies not included in the value of the products. It is calculated without making deductions for depreciation of fabricated assets or for depletion and degradation of natural resources. Data are in current U.S. dollars. Dollar figures for GDP are converted from domestic currencies using single year official exchange rates. For a few countries where the official exchange rate does not reflect the rate effectively applied to actual foreign exchange transactions, an alternative conversion factor is used. 
Industry, value added (current US\$):

Industry corresponds to ISIC divisions 10-45 and includes manufacturing (ISIC divisions 15-37). It comprises value added in mining, manufacturing (also reported as a separate subgroup), construction, electricity, water, and gas. Value added is the net output of a sector after adding up all outputs and subtracting intermediate inputs. It is calculated without making deductions for depreciation of fabricated assets or depletion and degradation of natural resources. The origin of value added is determined by the International Standard Industrial Classification (ISIC), revision 3. Data are in current U.S. dollars.

\section{Manufacturing, value added (current US\$):}

Manufacturing refers to industries belonging to ISIC divisions 15-37. Value added is the net output of a sector after adding up all outputs and subtracting intermediate inputs. It is calculated without making deductions for depreciation of fabricated assets or depletion and degradation of natural resources. The origin of value added is determined by the International Standard Industrial Classification (ISIC), revision 3. Data are in current U.S. dollars.

\section{Goods exports (BoP, current US\$):}

Goods exports refer to all movable goods (including nonmonetary gold) involved in a change of ownership from residents to nonresidents. The category includes goods previously included in services: goods received or sent for processing and their subsequent export or import in the form of processed goods, repairs on goods, and goods procured in ports by carriers. Data are in current U.S. dollars.

\section{Manufactures exports (current US\$):}

Manufactures comprise commodities in SITC sections 5 (chemicals), 6 (basic manufactures), 7 (machinery and transport equipment), and 8 (miscellaneous manufactured goods), excluding division 68 (non-ferrous metals).

\section{High-technology exports (current US\$):}

High-technology exports are products with high R\&D intensity, such as in aerospace, computers, pharmaceuticals, scientific instruments, and electrical machinery. Data are in current U.S. dollars.

Table 3 provides the definitions of the independent and dependent variables introduced in the research model as follows: 
Table 3: Definition of Independent Variables (IV) and Dependent Variables (DV)

\begin{tabular}{|c|c|}
\hline \multicolumn{2}{|l|}{ Independent variables } \\
\hline Industry / GDP & $\begin{array}{l}\text { Share of the national industrial sector in the national gross } \\
\text { domestic product }\end{array}$ \\
\hline Manufacturing / GDP & $\begin{array}{l}\text { Share of the national manufacturing sector in the national } \\
\text { gross domestic product }\end{array}$ \\
\hline Industry / WW Industry & $\begin{array}{l}\text { Share of the national industrial sector in the worldwide } \\
\text { industrial sector }\end{array}$ \\
\hline $\begin{array}{l}\text { Manufacturing / WW Manufactur- } \\
\text { ing }\end{array}$ & $\begin{array}{l}\text { Share of the national manufacturing sector in the worldwide } \\
\text { manufacturing sector }\end{array}$ \\
\hline \multicolumn{2}{|l|}{ Dependent variables } \\
\hline Exports Goods / GDP & $\begin{array}{l}\text { Share of the national exports of goods in the national gross } \\
\text { domestic product }\end{array}$ \\
\hline Exports Manufactures / GDP & $\begin{array}{l}\text { Share of the national exports of manufactures in the national } \\
\text { gross domestic product }\end{array}$ \\
\hline Exports High Technology / GDP & $\begin{array}{l}\text { Share of the national exports of high technology in the } \\
\text { national gross domestic product }\end{array}$ \\
\hline $\begin{array}{l}\text { Exports Goods / WW Exports } \\
\text { Goods }\end{array}$ & $\begin{array}{l}\text { Share of the national exports of goods in the worldwide } \\
\text { exports of goods }\end{array}$ \\
\hline $\begin{array}{l}\text { Exports Manufactures / WW } \\
\text { Exports Manufactures }\end{array}$ & $\begin{array}{l}\text { Share of the national exports of manufactures in the world- } \\
\text { wide exports of manufactures }\end{array}$ \\
\hline $\begin{array}{l}\text { Exports High Technology / WW } \\
\text { Exports High Technology }\end{array}$ & $\begin{array}{l}\text { Share of the national exports of high technology in the } \\
\text { worldwide exports of high technology }\end{array}$ \\
\hline
\end{tabular}

With reference to the deduced research model and the formulated assumptions, the specification of the independent and dependent variables as relevant GDP related and Exports related shares and the postulated causalities are shown in Table 4: 
Table 4: Deduced Hypotheses

\begin{tabular}{|c|c|c|}
\hline Hypotheses & $\begin{array}{c}\text { Independent Variables } \\
\text { (GDP related) }\end{array}$ & $\begin{array}{l}\text { Dependent Variables } \\
\text { (Exports related) }\end{array}$ \\
\hline \multicolumn{3}{|c|}{$\begin{array}{l}\text { Hypothetical Causality: } \\
\text { The increase of the independent variable results in the increase of the dependent variable. } \\
\text { The decrease of the independent variable results in the decrease of the dependent variable. }\end{array}$} \\
\hline & National & National \\
\hline 1 & Industry / GDP & Exports Goods / GDP \\
\hline 2 & Manufacturing / GDP & Exports Manufactures / GDP \\
\hline \multirow[t]{2}{*}{3} & Manufacturing / GDP & Exports High Technology / GDP \\
\hline & International & International \\
\hline 4 & Industry / WW Industry & Exports Goods / WW Exports Goods \\
\hline 5 & Manufacturing / WW Manufacturing & Exports Manufactures / WW Exports Manufactures \\
\hline \multirow[t]{2}{*}{6} & Manufacturing / WW Manufacturing & Exports High Technology / WW Exports High Technology \\
\hline & National & International \\
\hline 7 & Industry / GDP & Exports Goods / WW Exports Goods \\
\hline 8 & Manufacturing / GDP & Exports Manufactures / WW Exports Manufactures \\
\hline \multirow[t]{2}{*}{9} & Manufacturing / GDP & Exports High Technology / WW Exports High Technology \\
\hline & International & National \\
\hline 10 & Industry / WW Industry & Exports Goods / GDP \\
\hline 11 & Manufacturing / WW Manufacturing & Exports Manufactures / GDP \\
\hline 12 & Manufacturing / WW Manufacturing & Exports High Technology / GDP \\
\hline
\end{tabular}

\section{Methods of Analysis}

The analysis process is divided into three steps by taking a comparative perspective in each one. In the first step, a descriptive trend analysis with focus on the development of the independent and dependent variables was executed. The research goal in this step was the examination of general tendencies of the postulated variables during the analysed time period and a first evaluation of the deduced hypotheses. 
The value of the findings generated by a simple descriptive analysis is limited. Therefore, in the second step, a correlation analysis was conducted in order to examine the postulated relationship between the independent and dependent variables. The statistical results, expressed by the Pearson correlation coefficient, can vary between values of -1 and 1 , whereby a value of 0 indicates no correlation between the variables, and a value of 1 or -1 indicates perfect correlation. A perfect linear correlation of 1 indicates a positive increasing relationship between the analysed variables. On the other side, a perfect linear correlation of -1 indicates a negative increasing relationship. As an interpretation rule for the postulated hypothesis we can determine: The closer the computed correlation coefficient is to 1 , the closer the relationship between the examined variables.

The correlation coefficient only indicates a statistical relationship between variables, but does not prove a causal relationship. In order to overcome this methodical shortcoming, in the third step, a simple linear regression analysis was performed. The indicator used for the hypotheses testing is the coefficient of determination $\mathrm{R}^{2}$, which can achieve values between 0 and 1 . With regard to the causality-related confirmation of the postulated hypotheses the following decision rule can be determined: The statistical probability in favour of the acceptance of a hypothesis increases with a value close to 1 for $\mathrm{R}^{2}$.

By applying time series analysis the possibility of bias caused by auto correlation, a condition whereby the value of a specific variable of a time series is determined by the immediately preceding variable, has to be considered. Therefore, within the framework of the underlying study the Durbin-Watson-Test was executed. The results of the Durbin-Watson-Test can take values between 0 and 4 . Values close to 0 and 4 indicate the existence of auto correlation. A value of 2 or close to 2 signals a decreasing probability of an existing auto correlation.

The data set used in this study is based on the World Bank report covering the World Development Indicators. Economies included in the analysis are the P.R. China, Japan, South Korea, Singapore and Thailand covering the time period from 1990 to 2010.

\section{Limitations}

The development and application of specific research models as a limited attempt to explain complex realities with scientific methods is generally at risk of biased results. For the underlying study, the following limitations need to be stated and considered for the interpretation of the results:

- Data quality: The data used in this study is based on World Bank statistics. As an international organisation, the World Bank collects relevant data from each economy. The quality of the data reported by each country depends 
strongly on the usage of accurate and international standardised data collecting methods, otherwise one to one comparison on a global level is limited.

- Data equivalence: The GDP-related variables and Exports-related variables determined in this study are high level aggregates. The limited equivalence between GDP-aggregates and Exports-aggregates is a potential source of bias. The usage of different category systems for national sector-related GDP indicators and internationally traded products results in nonhomogenous variables equivalence.

- National differences: The economic development of a country usually depends on a broad range of different factors. On the one hand, it is difficult and probably not possible to limit the research focus to the effect of a few influencing factors. Although comparative analysis is a helpful method to discover and to explain similarities, nevertheless countries and geographic regions can fundamentally differ in their paths of economic development and international trade relations.

\section{Results}

This section provides a description and interpretation of the results of the previously conducted examination. In the first step, a comparative cross-country analysis illustrates the development of the independent variables and dependent variables during the defined time period, considering national as well as international perspectives.

\section{National Perspective of Indicator Development}

Figure 3 shows the development of the relative shares of the national industrial sector in the national GDP. In 1990, the range of the national shares was between $31.9 \%$ in Singapore and $41.3 \%$ in China. During the analysed time period the shares for China and Thailand increased, the shares for Japan, South Korea, and Singapore decreased. In 2010, the shares ranged between $27.4 \%$ in Japan and $46.7 \%$ in China. 
Figure 3 Development of the independent variable 'Industry / GDP'

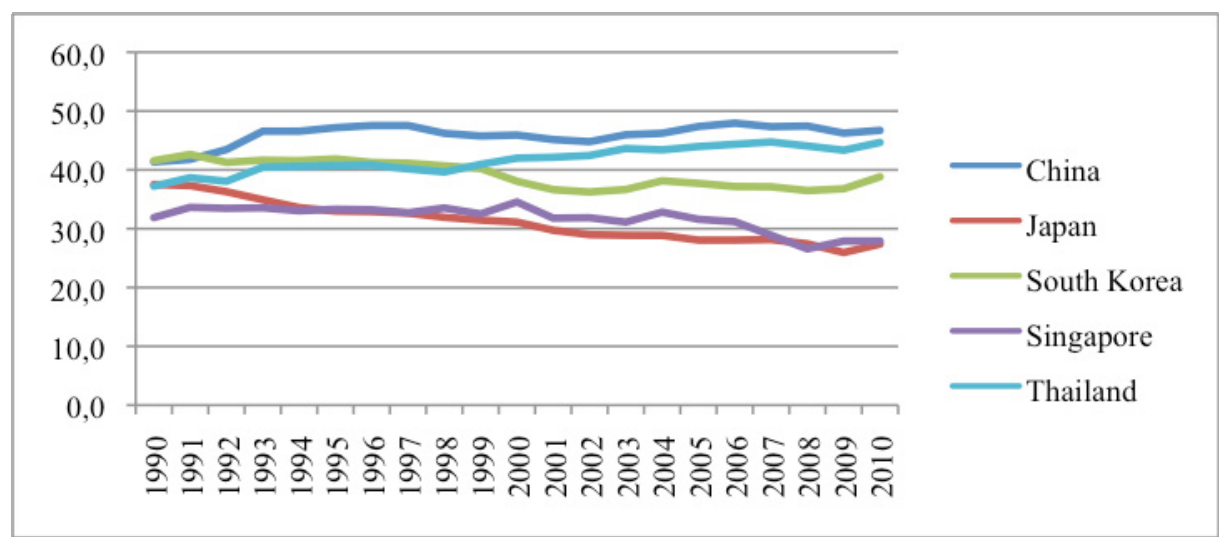

Figure 4 visualises the relative shares of the national manufacturing industry in the national GDP. The shares in 1990 ranged between $25.1 \%$ in Singapore and $32.7 \%$ in China. Over two observed decades, the shares rose in South Korea and Thailand, and fell in China, Japan. and Singapore. In 2010, the national manufacturing industries contributed with shares ranging from $19.5 \%$ up to $35.6 \%$ to the national GDPs.

Figure 4 Development of the independent variable 'Manufacturing / GDP'

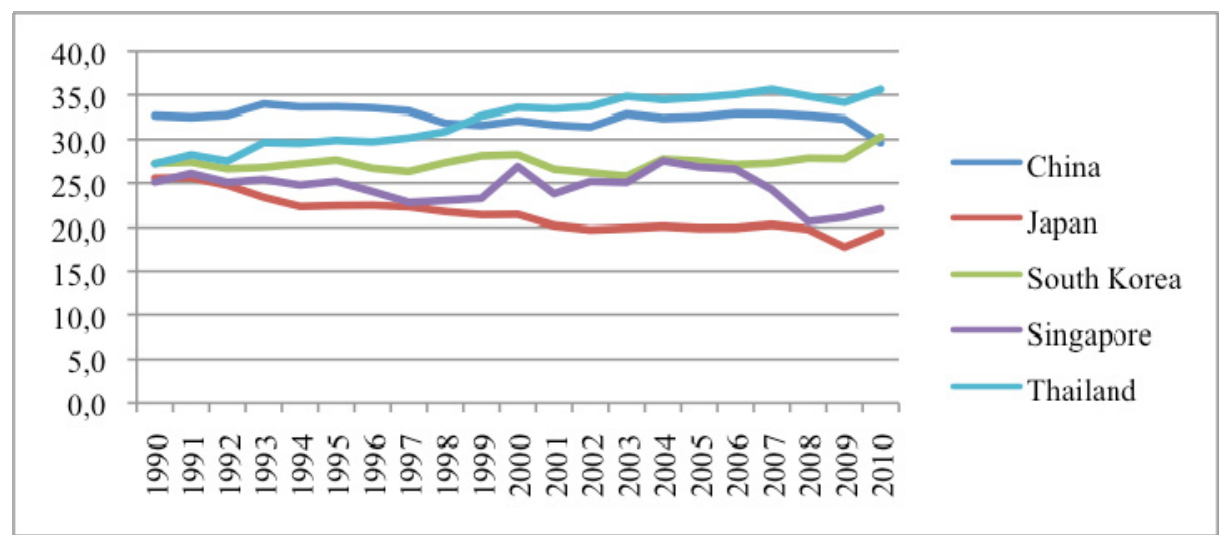

Figure 5 indicates the development of the relative share of the national exports of goods in the national GDP for each economy. Singapore is an outstanding example of a country with a very strong trading sector achieving remarkable export shares of $151.5 \%$ in 1990 and $168.2 \%$ in 2010. Nevertheless, a significant growth of export shares can be stated for each country, starting with values ranging from $9.1 \%$ to $26.7 \%$ in 1990 and values between $13.4 \%$ and $60.7 \%$ in 2010 , excluding Singapore. 
Figure 5 Development of the dependent variable 'Exports Goods / GDP'

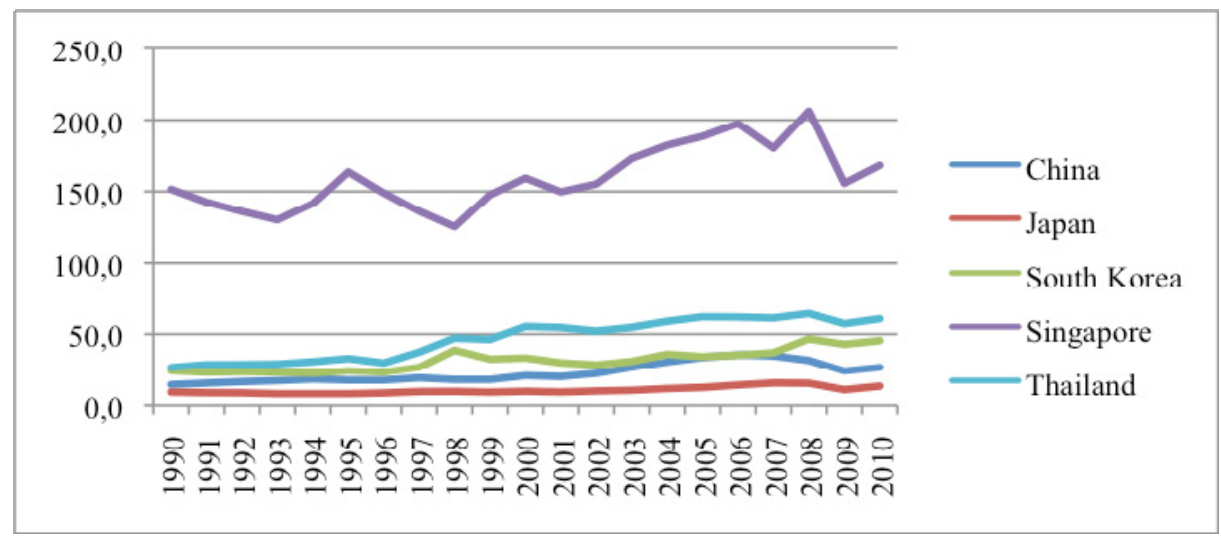

Figure 6 paints a similar picture with regard to the development of the relative share of national exports of manufactured goods in the national GDP. Again, the values for Singapore were extraordinary high, growing from $104.6 \%$ in 1990 to $120.7 \%$ in 2010. For the other economies a steady growth of the relevant share could be realised during the analysis period as well. Starting with a value range between $8.9 \%$ and $23.1 \%$ in 1990 the scope increased to $12.5 \%$ and up to $46.1 \%$ in 2010 .

Figure 6 Development of the dependent variable 'Exports Manufactures / GDP'

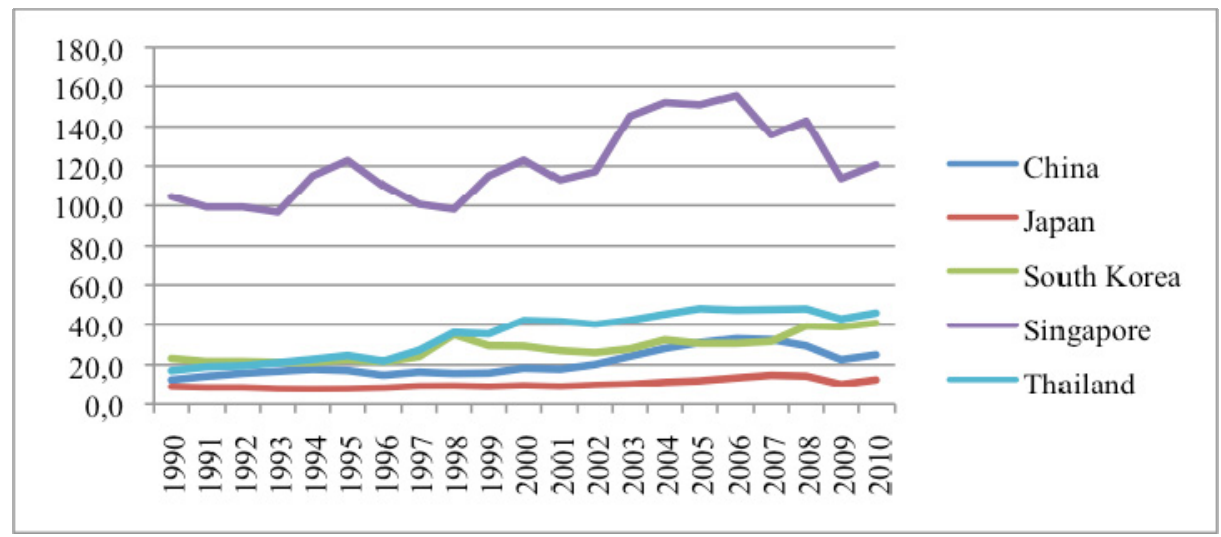

Figure 7 states the development of the relative shares of the national exports of high technology products in the national GDP. Once more, Singapore achieved significantly higher values compared to the other observed economies. The relevant share was $41.7 \%$ in 1990 and increased to $60.2 \%$ in 2010 . China, South Korea, and Thailand achieved growth between 1990 and 2010. Japan's share kept a relative steady and low level during the same time period in contrast to the other countries. The 
values ranged between 1\% (China 1992) and 4.2\% in 1990. For 2010, a value range from $2.2 \%$ and $11.2 \%$ (South Korea 2009) could be achieved.

Figure 7 Development of the dependent variable 'Exports High Technology / GDP'

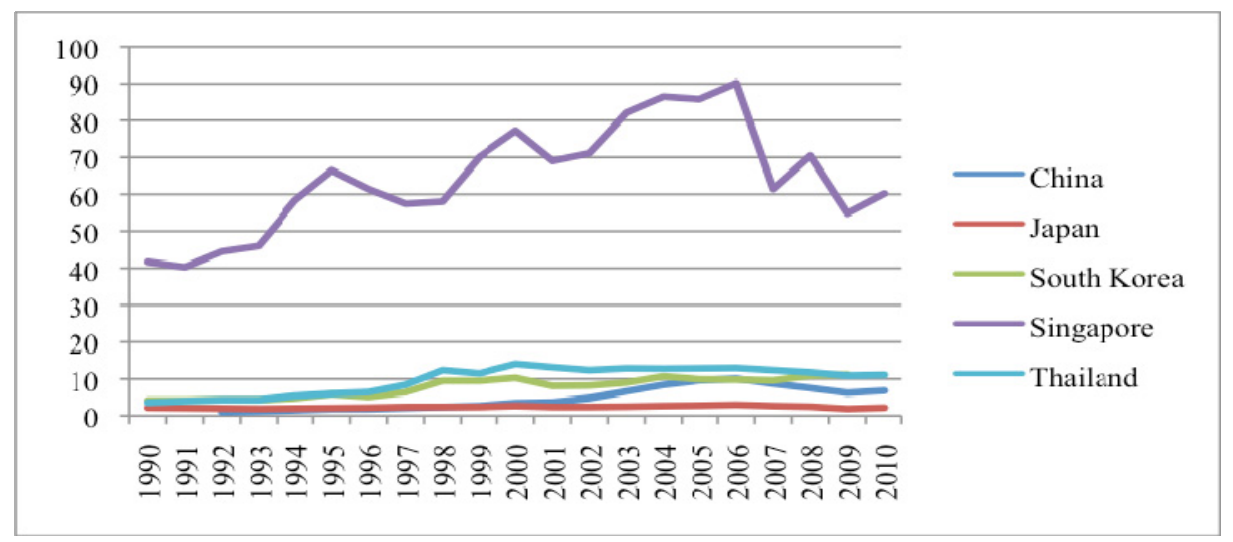

\section{International Perspective of Indicator Development}

Figure 8 shows the changes of the relative share of national GDP in the worldwide GDP. This figure and the following ones signal the changing roles of China and Japan within the global economy. While China's economy achieved a strong growth performance with shares increasing from $1.6 \%$ in 1990 up to $9.4 \%$ in 2010, Japan lost its dominant position, starting with a share value of $14.1 \%$ in 1990 and achieving a share of $8.7 \%$ in 2010 . For South Korea, Singapore and Thailand a relatively constant growth of the relevant shares was observed.

Figure 8 Development of 'GDP / WW GDP'

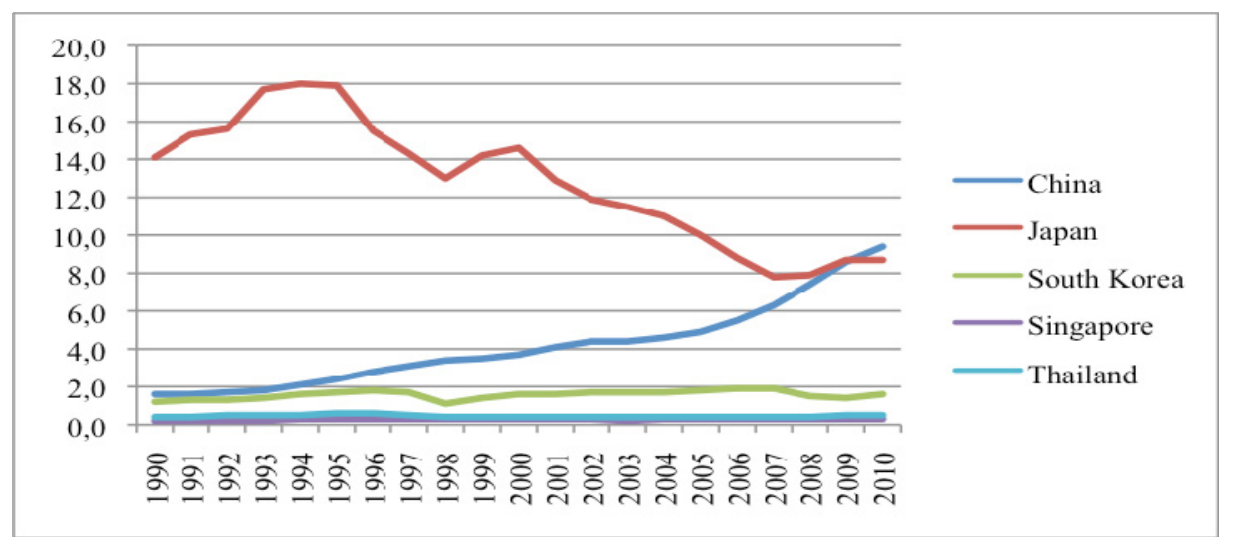


Figure 9 demonstrates the development of the relative shares of the national industry sector in the worldwide industry sector. A remarkable growth could be observed for China with a starting point of $2.2 \%$ in 1990 and a value of $16.1 \%$ in 2010 . On the other hand, the relevant share dropped substantially and in a sustained way for Japan with a value of $17.1 \%$ in 1990 and a relative share of $8.7 \%$ in 2010 . South Korea, Singapore, and Thailand achieved increasing shares during the analysed time period.

Figure 9 Development of the independent variable 'Industry / WW Industry'

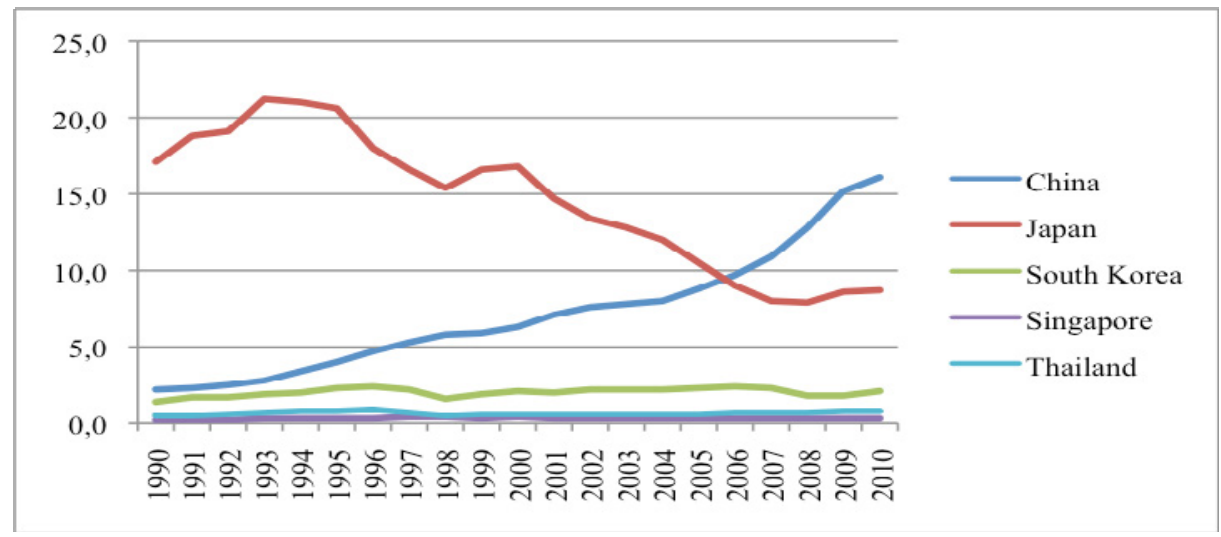

Figure 10 states the development of the relative shares of the national manufacturing sector in the worldwide manufacturing sector for the time period from 1998 to 2010 . While China increased its share from 5.5\% in 1998 up to $16.8 \%$ in 2010, Japan's relative share declined from $14.4 \%$ in 1998 to $10.2 \%$ in 2010 . South Korea and Thailand achieved growth whereas Singapore remained on a steady level.

Figure 10 Development of the independent variable 'Manufacturing / WW Manufacturing'

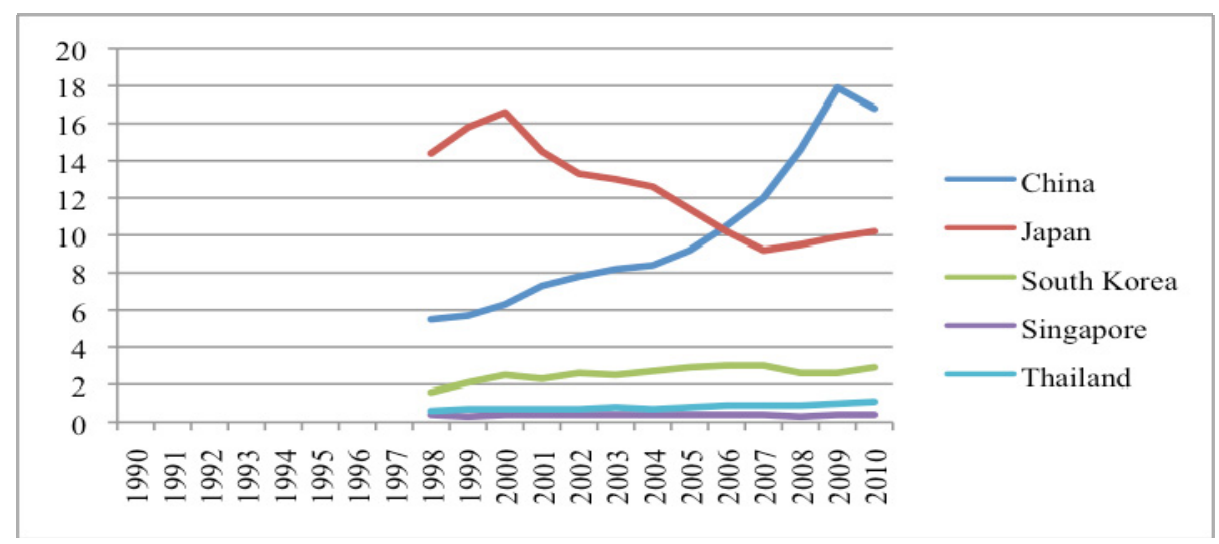


Figure 11 indicates the development of the relative shares of the national exports of goods in the worldwide exports of goods. China performed an outstanding rise of its share starting at $1.5 \%$ in 1990 ending up at $10.6 \%$ in 2010. Japan's relative share decreased from $8.1 \%$ in 1990 to $4.9 \%$ in 2010 . For South Korea, Singapore, and Thailand a steady growth could be observed.

Figure 11 Development of the dependent variable 'Exports Goods / WW Exports Goods'

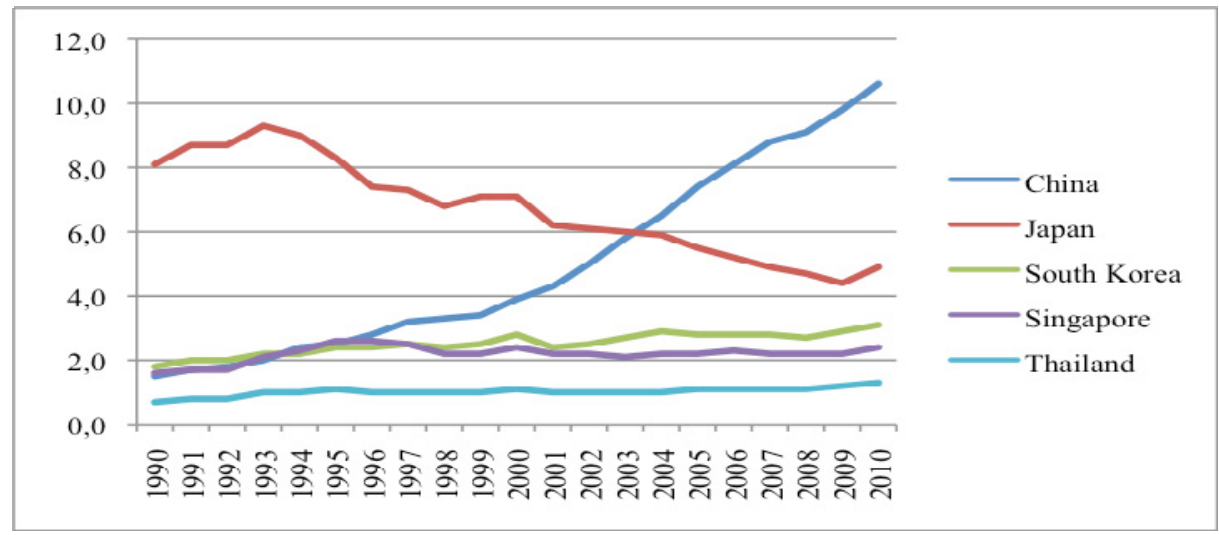

Figure 12 visualises the development of the relative share of the national exports of manufactured products in the worldwide exports of manufactured products. The outstanding growth of China can be highlighted once more. The Chinese relative share in 1990 was $1.8 \%$ and reached $14.1 \%$ in 2010 . In contrast to the Chinese development, the Japanese share dropped from $11 \%$ in 1990 to $6.5 \%$ in 2010 . The relative shares of South Korea, Singapore, and Thailand also increased between 1990 and 2010.

Figure 12 Development of the dependent variable 'Exports Manufactures / WW Exports Manufactures'

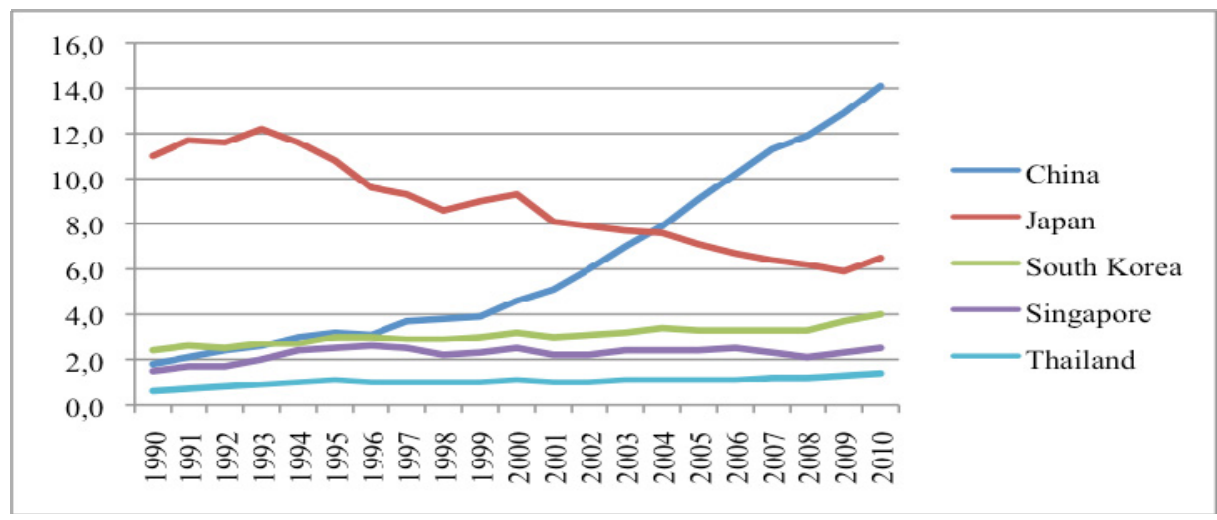


Finally, Figure 13 presents the development of the relative share of the national exports of high technology products in the worldwide exports of high technology products. For China, a tremendous increase of the relative share could be observed. Starting at $0.8 \%$ in 1992 , the Chinese share performed a significant increase up to $22.1 \%$ in 2010 . On the other side, the Japanese share decreased from $14.6 \%$ in 1990 to $6.7 \%$ in 2010 . The relative shares of South Korea, Singapore, and Thailand increased as well.

Figure 13 Development of the dependent variable 'Exports High Technology / WW Exports High Technology'

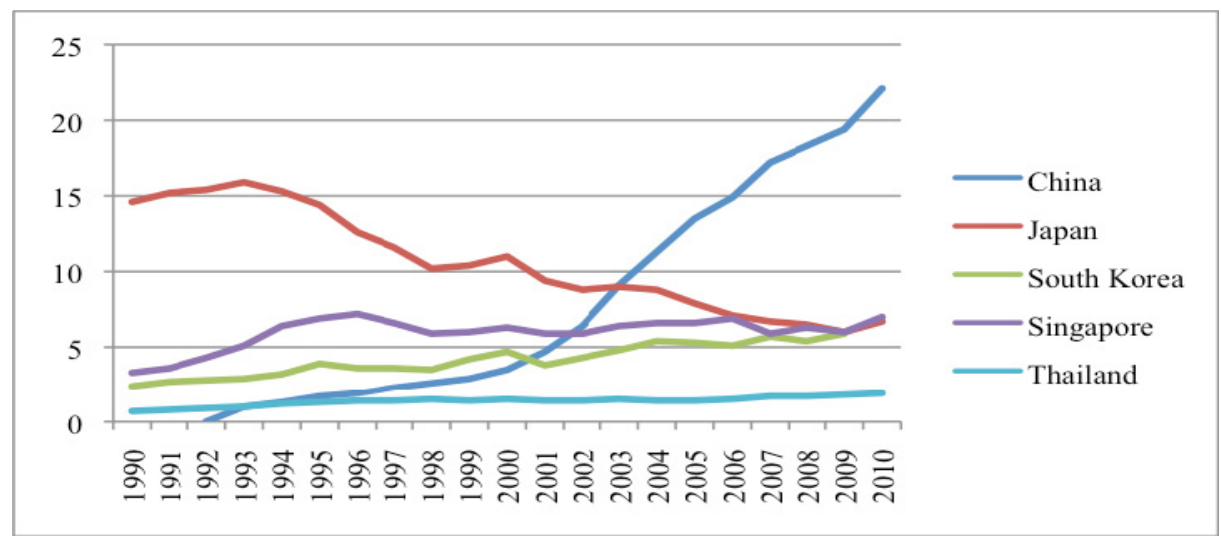

The following results from this first analysis step can be highlighted:

- The contributions of the industrial sector to the GDP in 2010 in China (46.7\%), South Korea (38.8\%), and Thailand (44.7\%) were significantly higher than in Japan (27.4\%) and Singapore (27.9\%).

- In accordance with the development of the industrial sector, the shares of the manufacturing sector in the GDP in 2010 were also higher in China (29.6\%), South Korea (30.3\%), and Thailand (35.6\%) compared with Japan (19.5\%) and Singapore (22.1\%).

- With reference to the share of the exports of goods, of manufactures, and of high technology products in the GDP, Singapore achieved impressive numbers that underline the sustaining role of Singapore as an important international trading hub.

- In contrast to Singapore, the international exports relations are of relatively minor importance for Japan. 
- China and Japan are definitely global economic players, a fact that is confirmed by their relatively high shares of their national GDP in the worldwide GDP. The same conclusion can be drawn for the Chinese and Japanese industrial and manufacturing sectors.

- On a global level, China is the undisputed largest trading nation in East Asia and Southeast Asia, especially in the exports of high technology products with a share of $22.1 \%$ in 2010 .

- Finally, the most interesting conclusion that can be drawn is the fact that China has replaced Japan as largest economy in the East Asian and Southeast Asian region.

\section{Hypotheses Testing}

In the next step, the hypotheses will be tested by the results of the descriptive trend analysis. Table 5 indicates the 12 hypotheses deduced from the developed research model. The hypotheses postulate a causal relationship between the independent GDP-related variables (IV) and the dependent Exports-related variables (DV). By applying the variables-related development of the trends to the research model, expressed by increasing, decreasing, and stable developments of the variables, the following results could be stated:

- Number of confirmed hypotheses at single country level: China (6), Japan (6), South Korea (10), Singapore (2), and Thailand (12).

- At cross-country level: The strongest consensus was given for the hypotheses addressing causalities on the international level. One hypothesis could be confirmed for all countries: If the share of the national industrial sector in the worldwide industrial sector increases (decreases) then the share of national exports of goods in the worldwide exports of goods increases (decreases) as well. Furthermore, if we consider the extraordinary role of Singapore as import-export-hub and the bias potentially given by the comparison of a relatively small manufacturing sector and a relatively strong trading sector, then by taking the pure international perspective, one can conclude a basic causality in the sense that the share of the GDP-related variables directly effects the share of the Exports-related variables. The weakest consensus was given for the hypotheses addressing causalities on the national level only. The hypotheses in this segment were confirmed completely for Thailand and predominantly for South Korea. For China, Japan, and Singapore no hypothesis could be confirmed. 
Table 5: Results of the descriptive trend analysis

$(+=$ increase of the variable, $-=$ decrease of the variable, $x=$ no change of the variable $)$

\begin{tabular}{|c|c|c|c|c|c|c|c|c|c|c|c|}
\hline $\begin{array}{c}\text { Independent } \\
\text { Variables } \\
\text { (GDP related) }\end{array}$ & $\begin{array}{l}\text { Dependent } \\
\text { Variables } \\
\text { (Exports } \\
\text { related) } \\
\end{array}$ & \multicolumn{2}{|c|}{ China } & \multicolumn{2}{|c|}{ Japan } & \multicolumn{2}{|c|}{ South Korea } & \multicolumn{2}{|c|}{ Singapore } & \multicolumn{2}{|c|}{ Thailand } \\
\hline \multicolumn{2}{|c|}{$\begin{array}{l}\text { Hypothesis: } \\
\text { An increase (decrease) of the } \\
\text { independent variable results in } \\
\text { an increase (decrease) of the } \\
\text { dependent variable. }\end{array}$} & $\begin{array}{l}\text { Trend } \\
\text { IV }\end{array}$ & $\begin{array}{c}\text { Trend } \\
\text { DV }\end{array}$ & $\begin{array}{l}\text { Trend } \\
\text { IV }\end{array}$ & $\begin{array}{l}\text { Trend } \\
\text { DV }\end{array}$ & $\begin{array}{l}\text { Trend } \\
\text { IV }\end{array}$ & $\begin{array}{l}\text { Trend } \\
\text { DV }\end{array}$ & $\begin{array}{l}\text { Trend } \\
\text { IV }\end{array}$ & $\begin{array}{l}\text { Trend } \\
\text { DV }\end{array}$ & $\begin{array}{l}\text { Trend } \\
\text { IV }\end{array}$ & $\begin{array}{c}\text { Trend } \\
\text { DV }\end{array}$ \\
\hline National & National & & & & & & & & & & \\
\hline $\begin{array}{l}\text { IND / } \\
\text { GDP }\end{array}$ & $\begin{array}{c}\text { EXG / } \\
\text { GDP }\end{array}$ & - & + & - & + & - & + & - & + & + & + \\
\hline $\begin{array}{l}\text { MA / } \\
\text { GDP }\end{array}$ & $\begin{array}{c}\text { EXMA / } \\
\text { GDP }\end{array}$ & - & + & - & + & + & + & - & + & + & + \\
\hline $\begin{array}{l}\text { MA / } \\
\text { GDP }\end{array}$ & $\begin{array}{c}\text { EXHT / } \\
\text { GDP }\end{array}$ & - & + & - & $\mathrm{x}$ & + & + & - & + & + & + \\
\hline International & Interna- & & & & & & & & & & \\
\hline $\begin{array}{c}\text { IND / } \\
\text { WWIND }\end{array}$ & $\begin{array}{c}\text { EXG/ } \\
\text { WWEXG }\end{array}$ & + & + & - & - & + & + & + & + & + & + \\
\hline $\begin{array}{c}\text { MA / } \\
\text { WWMA }\end{array}$ & $\begin{array}{c}\text { EXMA / } \\
\text { WWEXMA }\end{array}$ & + & + & - & - & + & + & $\mathrm{x}$ & + & + & + \\
\hline $\begin{array}{c}\text { MA / } \\
\text { WWMA }\end{array}$ & $\begin{array}{c}\text { EXHT / } \\
\text { WWEXHT }\end{array}$ & + & + & - & - & + & + & $\mathrm{x}$ & + & + & + \\
\hline National & Interna- & & & & & & & & & & \\
\hline $\begin{array}{l}\text { IND / } \\
\text { GDP }\end{array}$ & $\begin{array}{c}\text { EXG/ } \\
\text { WWEXG }\end{array}$ & - & + & - & - & - & + & - & + & + & + \\
\hline $\begin{array}{l}\text { MA / } \\
\text { GDP }\end{array}$ & $\begin{array}{c}\text { EXMA / } \\
\text { WWEXMA }\end{array}$ & - & + & - & - & + & + & - & + & + & + \\
\hline $\begin{array}{l}\text { MA / } \\
\text { GDP }\end{array}$ & $\begin{array}{c}\text { EXHT / } \\
\text { WWEXHT }\end{array}$ & - & + & - & - & + & + & - & + & + & + \\
\hline International & National & & & & & & & & & & \\
\hline $\begin{array}{c}\text { IND / } \\
\text { WWIND }\end{array}$ & $\begin{array}{c}\text { EXG / } \\
\text { GDP }\end{array}$ & + & + & - & + & + & + & + & + & + & + \\
\hline $\begin{array}{c}\text { MA / } \\
\text { WWMA }\end{array}$ & $\begin{array}{c}\text { EXMA / } \\
\text { GDP }\end{array}$ & + & + & - & + & + & + & $\mathrm{x}$ & + & + & + \\
\hline $\begin{array}{c}\text { MA / } \\
\text { WWMA }\end{array}$ & $\begin{array}{c}\text { EXHT / } \\
\text { GDP }\end{array}$ & + & + & - & $\mathrm{x}$ & + & + & $\mathrm{x}$ & + & + & + \\
\hline
\end{tabular}

(IV=Independent Variable; $\quad$ DV=Dependent $\quad$ Variable; IND/GDP=Industry/GDP; MA/GDP=Manufacturing/GDP; IND/WWIND=Industry/Worldwide Industry; MA/WWMA =Manufacturing/Worldwide Manufacturing; EXG/GDP $=$ Exports Goods/GDP; EXMA/GDP= Exports Manufactures/GDP; EXHT/GDP=Exports High Technology/GDP; EXG/WWEXG= Exports Goods/Worldwide Exports Goods; EXMA/WWEXMA $=$ Exports Manufactures/Worldwide Exports Manufactures; EXHT/WWEXHT= Exports High Technology/Worldwide Exports High Technology) 
As the results of the descriptive trend analysis can generally be qualified as vague and inadequate for the explanation of the postulated causal relations between the independent and dependent variables, a correlation analysis and a regression analysis were conducted.

Table 6 indicates the results of the correlation analysis and the regression analysis. By accepting a correlation coefficient (CC) of at least 0.5 and an $\mathrm{R}^{2}$ of at least 0.5 the following outcome was achieved:

- Number of confirmed hypotheses at single country level: China (5), Japan (6), South Korea (5), Singapore (1), and Thailand (10).

- At cross-country level: The strongest consensus was given once again for the hypotheses addressing causalities on the international level. The hypotheses testing by applying the correlation analysis as well as the regression analysis confirmed the results of the descriptive trend analysis in this segment. If the share of the national industrial sector in the worldwide industrial sectors increases (decreases) then the share of national exports of goods in the worldwide exports of goods increases (decreases) as well. The weakest consensus was given for the hypotheses addressing causalities on the international GDP-related level and the national Exports-related level.

Finally, in order to avoid bias by auto correlation the Durbin-Watson Test was conducted. The results are as follows (see Table 7 - Part 1 and Part 2):

- Number of confirmed hypotheses at single country level: China (0); Japan (2), South Korea (0), Singapore (1), and Thailand (3).

- At cross-country level: There is no general consensus. 
Table 6: Results of the correlation analysis and the regression analysis

\begin{tabular}{|c|c|c|c|c|c|c|c|c|c|c|c|}
\hline $\begin{array}{l}\text { Independent } \\
\text { Variables } \\
\text { (GDP related) }\end{array}$ & $\begin{array}{c}\text { Dependent } \\
\text { Variables } \\
\text { (Exports } \\
\text { related) } \\
\end{array}$ & \multicolumn{2}{|c|}{ China } & \multicolumn{2}{|c|}{ Japan } & \multicolumn{2}{|c|}{ South Korea } & \multicolumn{2}{|c|}{ Singapore } & \multicolumn{2}{|c|}{ Thailand } \\
\hline \multicolumn{2}{|c|}{$\begin{array}{c}\text { Hypothesis: } \\
\text { An increase (decrease) of the } \\
\text { independent variable results in } \\
\text { an increase (decrease) of the } \\
\text { dependent variable. }\end{array}$} & $\mathrm{CC}$ & $\mathbf{R}^{2}$ & $\mathrm{CC}$ & $\mathbf{R}^{2}$ & $\mathrm{CC}$ & $\mathbf{R}^{2}$ & $\mathrm{CC}$ & $\mathbf{R}^{2}$ & $\mathrm{CC}$ & $\mathbf{R}^{2}$ \\
\hline National & National & & & & & & & & & & \\
\hline $\begin{array}{l}\mathrm{IND} / \\
\text { GDP }\end{array}$ & $\begin{array}{c}\text { EXG / } \\
\text { GDP }\end{array}$ & 0.550 & 0.931 & -0.721 & 0.910 & -0.665 & 0.927 & -0.602 & 0.967 & 0.896 & $\begin{array}{c}0.94 \\
5 \\
\end{array}$ \\
\hline $\begin{array}{l}\text { MA / } \\
\text { GDP }\end{array}$ & $\begin{array}{c}\text { EXMA / } \\
\text { GDP }\end{array}$ & -0.107 & 0.913 & -0.592 & 0.928 & 0.608 & 0.962 & 0.270 & 0.977 & 0.976 & $\begin{array}{c}0.94 \\
9\end{array}$ \\
\hline $\begin{array}{l}\text { MA / } \\
\text { GDP }\end{array}$ & $\begin{array}{c}\text { EXHT / } \\
\text { GDP }\end{array}$ & -0.261 & 0.706 & -0.433 & 0.965 & 0.390 & 0.911 & 0.304 & 0.957 & 0.899 & $\begin{array}{c}0.92 \\
1 \\
\end{array}$ \\
\hline Internat. & Internat. & & & & & & & & & & \\
\hline $\begin{array}{c}\text { IND / } \\
\text { WWIND } \\
\end{array}$ & $\begin{array}{c}\text { EXG / } \\
\text { WWEXG }\end{array}$ & 0.973 & 0.987 & 0.973 & 0.991 & 0.579 & 0.985 & 0.727 & 0.985 & 0.591 & $\begin{array}{c}0.98 \\
2 \\
\end{array}$ \\
\hline $\begin{array}{c}\text { MA / } \\
\text { WWMA }\end{array}$ & $\begin{array}{c}\text { EXMA / } \\
\text { WWEXMA }\end{array}$ & 0.954 & 0.987 & 0.982 & 0.996 & 0.624 & 0.987 & 0.441 & 0.993 & 0.925 & $\begin{array}{c}0.99 \\
3 \\
\end{array}$ \\
\hline $\begin{array}{c}\text { MA / } \\
\text { WWMA }\end{array}$ & $\begin{array}{c}\text { EXHT / } \\
\text { WWEXHT }\end{array}$ & 0.941 & 0.955 & 0.978 & 0.998 & 0.794 & 0.991 & 0.152 & 0.989 & 0.862 & $\begin{array}{c}0.99 \\
1 \\
\end{array}$ \\
\hline National & Internat. & & & & & & & & & & \\
\hline $\begin{array}{l}\text { IND / } \\
\text { GDP }\end{array}$ & $\begin{array}{c}\text { EXG / } \\
\text { WWEXG }\end{array}$ & 0.487 & 0.762 & 0.930 & 0.984 & -0.717 & 0.969 & -0.055 & 0.981 & 0.818 & $\begin{array}{c}0.99 \\
2\end{array}$ \\
\hline $\begin{array}{l}\text { MA / } \\
\text { GDP }\end{array}$ & $\begin{array}{c}\text { EXMA / } \\
\text { WWEXMA }\end{array}$ & -0.431 & 0.711 & 0.892 & 0.979 & 0.558 & 0.989 & -0.040 & 0.977 & 0.825 & $\begin{array}{c}0.98 \\
8\end{array}$ \\
\hline $\begin{array}{l}\text { MA / } \\
\text { GDP }\end{array}$ & $\begin{array}{c}\text { EXHT / } \\
\text { WWEXHT }\end{array}$ & -0.435 & 0.583 & 0.897 & 0.952 & 0.309 & 0.943 & -0.139 & 0.962 & 0.849 & $\begin{array}{c}0.97 \\
7\end{array}$ \\
\hline Internat. & National & & & & & & & & & & \\
\hline $\begin{array}{c}\text { IND / } \\
\text { WWIND }\end{array}$ & $\begin{array}{c}\text { EXG / } \\
\text { GDP }\end{array}$ & 0.716 & 0.877 & -0.909 & 0.770 & 0.026 & 0.931 & -0.039 & 0.950 & -0.009 & $\begin{array}{c}0.89 \\
8 \\
\end{array}$ \\
\hline $\begin{array}{c}\text { MA / } \\
\text { WWMA }\end{array}$ & $\begin{array}{c}\text { EXMA / } \\
\text { GDP }\end{array}$ & 0.472 & 0.891 & -0.844 & 0.880 & 0.092 & 0.962 & 0.013 & 0.973 & 0.624 & $\begin{array}{c}0.98 \\
2 \\
\end{array}$ \\
\hline $\begin{array}{c}\text { MA / } \\
\text { WWMA }\end{array}$ & $\begin{array}{c}\text { EXHT / } \\
\text { GDP }\end{array}$ & 0.478 & 0.861 & 0.020 & 0.954 & 0.228 & 0.975 & 0.068 & 0.970 & -0.575 & $\begin{array}{c}0.95 \\
4\end{array}$ \\
\hline
\end{tabular}

(IV=Independent Variable; $\quad \mathrm{DV}=$ Dependent $\quad$ Variable; $\quad \mathrm{IND} / \mathrm{GDP}=$ Industry/GDP; MA/GDP=Manufacturing/GDP; $\quad$ IND/WWIND=Industry/Worldwide $\quad$ Industry; $\mathrm{MA} / \mathrm{WWMA}=$ Manufacturing/Worldwide Manufacturing; $\mathrm{EXG} / \mathrm{GDP}=$ Exports Goods/GDP; EXMA/GDP= Exports Manufactures/GDP; EXHT/GDP=Exports High Technology/GDP; EXG/WWEXG= Exports Goods/Worldwide Exports Goods; EXMA/WWEXMA $=$ Exports Manufactures/Worldwide Exports Manufactures; EXHT/WWEXHT= Exports High Technology/Worldwide Exports High Technology) 
Table 7: (Part 1 - East Asian economies: China, Japan, South Korea): Results of the correlation analysis and the regression analysis considering the Durban-Watson Test

\begin{tabular}{|c|c|c|c|c|c|c|c|c|c|c|}
\hline $\begin{array}{c}\text { IV } \\
\text { (GDP } \\
\text { related) }\end{array}$ & $\begin{array}{c}\text { DV } \\
\text { (Exports } \\
\text { related) }\end{array}$ & \multicolumn{3}{|c|}{ China } & \multicolumn{3}{|c|}{ Japan } & \multicolumn{3}{|c|}{ South Korea } \\
\hline \multicolumn{2}{|c|}{$\begin{array}{c}\text { Hypothesis: } \\
\text { An increase (decrease) of } \\
\text { the independent variable } \\
\text { results in an increase } \\
\text { (decrease) of the } \\
\text { dependent variable. }\end{array}$} & $\mathrm{CC}$ & $\mathrm{R}^{2}$ & DW & $\mathrm{CC}$ & $\mathrm{R}^{2}$ & DW & $\mathrm{CC}$ & $\mathrm{R}^{2}$ & DW \\
\hline National & National & & & & & & & & & \\
\hline $\begin{array}{l}\text { IND / } \\
\text { GDP }\end{array}$ & $\begin{array}{l}\text { EXG / } \\
\text { GDP }\end{array}$ & 0.550 & 0.302 & 0.190 & -0.721 & 0.521 & 0.963 & -0.665 & 0.442 & 0.748 \\
\hline $\begin{array}{l}\text { MA / } \\
\text { GDP }\end{array}$ & $\begin{array}{c}\text { EXMA / } \\
\text { GDP }\end{array}$ & -0.107 & 0.011 & 0.179 & -0.592 & 0.351 & 0.907 & 0.608 & 0.369 & 0.623 \\
\hline $\begin{array}{l}\text { MA / } \\
\text { GDP }\end{array}$ & $\begin{array}{c}\text { EXHT / } \\
\text { GDP }\end{array}$ & -0.261 & 0.068 & 0.165 & -0.433 & 0.188 & 0.845 & 0.390 & 0.152 & 0.142 \\
\hline Internat. & Internat. & & & & & & & & & \\
\hline $\begin{array}{c}\text { IND / } \\
\text { WWIND }\end{array}$ & $\begin{array}{c}\text { EXG / } \\
\text { WWEXG }\end{array}$ & 0.973 & 0.947 & 0.374 & 0.973 & 0.947 & 0.532 & 0.579 & 0.336 & 0.355 \\
\hline $\begin{array}{c}\text { MA / } \\
\text { WWMA }\end{array}$ & $\begin{array}{c}\text { EXMA / } \\
\text { WWEXMA }\end{array}$ & 0.954 & 0.909 & 0.828 & 0.982 & 0.964 & 1.566 & 0.624 & 0.389 & 0.503 \\
\hline $\begin{array}{c}\text { MA / } \\
\text { WWMA }\end{array}$ & $\begin{array}{c}\text { EXHT / } \\
\text { WWEXHT }\end{array}$ & 0.941 & 0.885 & 0.920 & 0.978 & 0.956 & 1.259 & 0.794 & 0.631 & 0.799 \\
\hline National & Internat. & & & & & & & & & \\
\hline $\begin{array}{l}\text { IND / } \\
\text { GDP }\end{array}$ & $\begin{array}{c}\text { EXG / } \\
\text { WWEXG }\end{array}$ & 0.487 & 0.237 & 0.118 & 0.930 & 0.866 & 0.601 & -0.717 & 0.514 & 0.932 \\
\hline $\begin{array}{l}\text { MA / } \\
\text { GDP }\end{array}$ & $\begin{array}{c}\text { EXMA / } \\
\text { WWEXMA }\end{array}$ & -0.431 & 0.186 & 0.183 & 0.892 & 0.796 & 0.656 & 0.558 & 0.311 & 0.337 \\
\hline $\begin{array}{l}\text { MA / } \\
\text { GDP }\end{array}$ & $\begin{array}{c}\text { EXHT / } \\
\text { WWEXHT }\end{array}$ & -0.435 & 0.189 & 0.162 & 0.897 & 0.805 & 0.615 & 0.309 & 0.096 & 0.163 \\
\hline Internat. & National & & & & & & & & & \\
\hline $\begin{array}{c}\text { IND / } \\
\text { WWIND }\end{array}$ & $\begin{array}{l}\text { EXG / } \\
\text { GDP }\end{array}$ & 0.716 & 0.513 & 0.442 & -0.909 & 0.827 & 1.602 & 0.026 & 0.001 & 0.329 \\
\hline $\begin{array}{c}\text { MA / } \\
\text { WWMA }\end{array}$ & $\begin{array}{c}\text { EXMA / } \\
\text { GDP }\end{array}$ & 0.472 & 0.222 & 0.456 & -0.844 & 0.713 & 1.943 & 0.092 & 0.008 & 0.498 \\
\hline $\begin{array}{c}\text { MA / } \\
\text { WWMA }\end{array}$ & $\begin{array}{c}\text { EXHT / } \\
\text { GDP }\end{array}$ & 0.478 & 0.228 & 0.341 & 0.020 & 0.000 & 0.904 & 0.228 & 0.052 & 1.141 \\
\hline
\end{tabular}

(IV=Independent Variable; $\quad \mathrm{DV}=$ Dependent $\quad$ Variable; $\quad \mathrm{IND} / \mathrm{GDP}=$ Industry/GDP; MA/GDP=Manufacturing/GDP; IND/WWIND=Industry/Worldwide Industry; MA/WWMA $=$ Manufacturing/Worldwide Manufacturing; EXG/GDP $=$ Exports Goods/GDP; EXMA/GDP= Exports Manufactures/GDP; EXHT/GDP=Exports High Technology/GDP; EXG/WWEXG= Exports Goods/Worldwide Exports Goods; EXMA/WWEXMA = Exports Manufactures/Worldwide Exports Manufactures; EXHT/WWEXHT= Exports High Technology/Worldwide Exports High Technology) 
Table 7: (Part 2 - Southeast Asian economies: Singapore, Thailand): Results of the correlation analysis and the regression analysis considering the Durban-Watson Test

\begin{tabular}{|c|c|c|c|c|c|c|c|}
\hline $\begin{array}{c}\text { IV } \\
\text { (GDP related) }\end{array}$ & $\begin{array}{c}\text { DV } \\
\text { (Exports related) }\end{array}$ & \multicolumn{3}{|c|}{ Singapore } & \multicolumn{3}{|c|}{ Thailand } \\
\hline \multicolumn{2}{|c|}{$\begin{array}{c}\text { Hypothesis: } \\
\text { An increase (decrease) of the } \\
\text { independent variable results in an } \\
\text { increase (decrease) of the depend- } \\
\text { ent variable. }\end{array}$} & $\mathrm{CC}$ & $\mathrm{R}^{2}$ & DW & $\mathrm{CC}$ & $\mathrm{R}^{2}$ & DW \\
\hline National & National & & & & & & \\
\hline $\begin{array}{l}\text { IND / } \\
\text { GDP }\end{array}$ & $\begin{array}{l}\text { EXG / } \\
\text { GDP }\end{array}$ & -0.602 & 0.362 & 1.032 & 0.896 & 0.803 & 0.989 \\
\hline $\begin{array}{l}\text { MA / } \\
\text { GDP }\end{array}$ & $\begin{array}{c}\text { EXMA / } \\
\text { GDP }\end{array}$ & 0.270 & 0.073 & 0.463 & 0.976 & 0.952 & 2.052 \\
\hline $\begin{array}{l}\text { MA / } \\
\text { GDP }\end{array}$ & $\begin{array}{l}\text { EXHT / } \\
\text { GDP }\end{array}$ & 0.304 & 0.092 & 0.443 & 0.899 & 0.809 & 0.759 \\
\hline Internat. & Internat. & & & & & & \\
\hline $\begin{array}{c}\text { IND / } \\
\text { WWIND }\end{array}$ & $\begin{array}{c}\text { EXG / } \\
\text { WWEXG }\end{array}$ & 0.727 & 0.529 & 1.043 & 0.591 & 0.349 & 0.723 \\
\hline $\begin{array}{c}\text { MA / } \\
\text { WWMA }\end{array}$ & $\begin{array}{c}\text { EXMA / } \\
\text { WWEXMA }\end{array}$ & 0.441 & 0.195 & 1.740 & 0.925 & 0.857 & 2.149 \\
\hline $\begin{array}{c}\text { MA / } \\
\text { WWMA }\end{array}$ & $\begin{array}{c}\text { EXHT / } \\
\text { WWEXHT }\end{array}$ & 0.152 & 0.023 & 1.737 & 0.862 & 0.743 & 1.231 \\
\hline National & Internat. & & & & & & \\
\hline $\begin{array}{l}\text { IND / } \\
\text { GDP }\end{array}$ & $\begin{array}{c}\text { EXG / } \\
\text { WWEXG }\end{array}$ & -0.055 & 0.003 & 0.419 & 0.818 & 0.669 & 0.669 \\
\hline $\begin{array}{l}\text { MA / } \\
\text { GDP }\end{array}$ & $\begin{array}{c}\text { EXMA / } \\
\text { WWEXMA }\end{array}$ & -0.040 & 0.002 & 0.448 & 0.825 & 0.680 & 0.450 \\
\hline $\begin{array}{l}\text { MA / } \\
\text { GDP }\end{array}$ & $\begin{array}{c}\text { EXHT / } \\
\text { WWEXHT }\end{array}$ & -0.139 & 0.019 & 0.363 & 0.849 & 0.721 & 0.451 \\
\hline Internat. & National & & & & & & \\
\hline $\begin{array}{c}\text { IND / } \\
\text { WWIND }\end{array}$ & $\begin{array}{l}\text { EXG / } \\
\text { GDP }\end{array}$ & -0.039 & 0.001 & 0.628 & -0.009 & 0.000 & 0.094 \\
\hline $\begin{array}{c}\text { MA / } \\
\text { WWMA }\end{array}$ & $\begin{array}{c}\text { EXMA / } \\
\text { GDP }\end{array}$ & 0.013 & 0.000 & 0.663 & 0.624 & 0.390 & 1.010 \\
\hline $\begin{array}{c}\text { MA / } \\
\text { WWMA }\end{array}$ & $\begin{array}{c}\text { EXHT / } \\
\text { GDP }\end{array}$ & 0.068 & 0.005 & 1.092 & -0.575 & 0.330 & 1.731 \\
\hline
\end{tabular}

(IV=Independent Variable; $\quad$ DV=Dependent $\quad$ Variable; $\quad$ IND/GDP=Industry/GDP; $\mathrm{MA} / \mathrm{GDP}=$ Manufacturing/GDP; $\quad$ IND/WWIND=Industry/Worldwide $\quad$ Industry; $\mathrm{MA} / \mathrm{WWMA}=$ Manufacturing/Worldwide Manufacturing; $\mathrm{EXG} / \mathrm{GDP}=$ Exports Goods/GDP; EXMA/GDP= Exports Manufactures/GDP; EXHT/GDP=Exports High Technology/GDP; EXG/WWEXG= Exports Goods/Worldwide Exports Goods; EXMA/WWEXMA = Exports Manufactures/Worldwide Exports Manufactures; EXHT/WWEXHT= Exports High Technology/Worldwide Exports High Technology) 


\section{Conclusions}

Theoretical as well as empirical research in the field of economics, in particular academics in development economics and international economics, postulate a direct relationship between economic development and the degree of international trade relations of economies. The research goal of the underlying study was the evaluation of generally accepted statements in the context of the causal relationship between economic development and international trade relations by applying a different and to some extent an innovative research approach in relation to traditional approaches. Based on the general causal relationship assuming a determining effect of the level of economic development on the degree of international trade activities of a country, instead of approaching absolute numbers, like absolute sector-related GDP, absolute exports or absolute growth rates, independent and dependent variables in terms of relative shares of economic indicators were introduced in the research model and used for hypotheses testing. This approach basically solves the problem of biased international comparison of national differences in economic size and trade volumes as well as in levels of economic development, in the sector-related and trade-related relevance, and in considering different levels of economic integration into the global economy.

For the hypotheses testing, a stepwise multi-methods approach by applying a descriptive trend analysis, a correlation analysis, and a regression analysis were conducted. The results of each method differ strongly. The strongest consensus and consistency between the analysed economies were achieved from the descriptive trend analysis, in terms of the number of confirmed hypotheses compared to the other applied methods. Although a significant discrepancy in regard to the accepted hypotheses exists between the economies, the most evident causal relationships between the level of economic development in the industrial sector and the intensity of exports of industrial products can be discovered by taking the international perspective in general, and for Thailand and South Korea in particular. Nevertheless, the descriptive trend analysis is proper to identify developmental trends, but the validity is limited to a first orientation phase in the research field only. In order to compensate that limitation, multivariate methods of analysis were applied. Actually, the postulated hypotheses could be mainly confirmed for the international research view as well as for Thailand. Finally, the probability of bias by auto correlation in econometric time series analysis always exists. To take account of this fact, a Durban-Watson test was executed. The results propose the rejection of the vast majority of the examined hypotheses. Once more, the potential existence of causal relationships in regard to the international perspective as well as for Thailand could be proven with some reservations to some extent only.

In order to summarise the key findings of this paper, the generally accepted postulate within the academic field of economics to causalities between economic 
development and international trade could not be confirmed by applying a research model introducing relative shares of output-related indicators on the national and international levels. Nevertheless, it can be stated that the basic finding of the underlying study revealed that an increase in the degree of integration into the global economy in terms of increased shares of the national industrial sector in the global industrial sector results in an increase of exports of industrial products, or more specifically, an increase of the share in the global exports volume of industrial products.

The results of this paper suggest further research, for example 1) by the adaptation of the research model and by integrating additional relevant socio-economic indicators as independent and dependent variables, 2) by increasing data quality and data accuracy, 3) by applying alternative analysis methods, and 4) by considering different industrial policies implemented by national governments. 


\section{LIST OF ABBREVIATIONS}

$\begin{array}{ll}\text { ASEAN }+3 & \text { Association of Southeast Asian Nations Plus Three } \\ \text { CC } & \text { Correlation coefficient } \\ \text { DV } & \text { Dependent variable } \\ \text { GDP } & \text { Gross Domestic Product } \\ \text { GNP } & \text { Gross National Product } \\ \text { HIC } & \text { High-income country } \\ \text { ISIC } & \text { International Standard Industrial Classification } \\ \text { IV } & \text { Independent variable } \\ \text { LIC } & \text { Low-income country } \\ \text { MIC } & \text { Middle-income country } \\ \text { P.R. China } & \text { People's Republic of China } \\ \text { R\&D } & \text { Research and Development } \\ \text { SITC } & \text { Standard International Trade Classification } \\ \text { US\$ } & \text { United States Dollar }\end{array}$




\section{REFERENCES}

Adams, Gerard F. and Yochanan Shachmurove. "Trade and Development Patterns in the East Asian Economies.” In Asian Economic Journal, 11/4, 1997, pp. 345-360

Adelman, Irma. "Development Economics - A Reassessment of Goals." In The American Economic Review, 65/2, 1975, pp. 302-309

Adelman, Irma. "Beyond Export-led Growth.” In World Development, 12/9, 1984, pp. 937-949

Akamatsu, Kaname. "A Theory of Unbalanced Growth in the World Economy." In Weltwirtschaftliches Archiv, 86, 1961, pp. 196-217

Akamatsu, Kaname. "A Historical Pattern of Economic Growth in Developing Countries." In The Developing Economies, 1/1, 1962, pp. 3-25

Akkemik, Ali K. Industrial Development in East Asia: A Comparative Look at Japan, Korea, Taiwan, and Singapore. Singapore: World Scientific Publishing, 2009

Albaum, Gerald, Jesper Strandskov, and Edwin Duerr. Internationales Marketing und Exportmanagement. München: Pearson, 2001

Bender, Dieter. "Internationaler Handel." In Vahlens Kompendium der Wirtschaftstheorie und Wirtschaftspolitik, Band 1, 9th Edtion. München: Vahlen, 2007

Bhagwati, Jagdish. "The Pure Theory of International Trade: A Survey." In The Economic Journal, 74/293, 1964, pp. 1-84

Breuss, Fritz. Außenwirtschaft, Band 1. Wien: Springer, 1997

Chacholiades, Miltiades. International Trade Theory and Policy. New York: McGraw-Hill, 1978

Chipman, John S. "A Survey of the Theory of International Trade: Part 1, The Classical Theory." In Econometrica, 33/3, 1965, pp. 477-519

Cypher, James M. and James L. Dietz. The Process of Economic Development. London and New York: Routledge, 2004

Dieter, Heribert. Die Asienkrise: Ursachen, Konsequenzen und die Rolle des Internationalen Währungsfonds. Marburg: Metropolis, 1998

Domar, Evsey D. "Capital Expansion, Rate of Growth, and Employment." In Econometrica, 14/2, 1946, pp. 137-147

Eibner, Wolfgang. Anwendungsorientierte Außenwirtschaft: Theorie \& Politik. München: Oldenbourg, 2006

Evans, George W., Seppo Honkapohja and Paul Romer. "Growth Cycles.” In The American Economic Review, 88/3, 1998, pp. 495-515

Farmer, Karl and Ronald Wendner. Wachstum und Außenhandel: Eine Einführung in die Gleichgewichtstheorie der Wachstums- und Außenhandelsdynamik. Heidelberg: Physica, 1999

Filippini, Carlo and Vasco Molini. "The Determinants of East Asian Trade Flows: A Gravity Equation Approach.” In Journal of Asian Economics, 14/5, 2003, pp. 695-711

Fourastié, Jean. Die große Hoffnung des zwanzigsten Jahrhunderts. Köln: Bund, 1969

Frankel, Jeffrey A. and David Romer. "Does Trade Cause Growth?” In The American Economic Review, 89/3, 1999, pp. 379-399

Götte, Rüdiger. Finanzkrisen: Mythos und Wahrheit, Anatomie und Geschichte: Warum Spekulationsblasen immer wieder entstehen, wie sie platzen - und wie Anleger sich vor ihnen schützen können. Stuttgart: ibidem-Verlag, 2012

Green, David Jay and Edgardo J. Campos. "Fiscal Lessons from the East Asian Financial Crisis." In Journal of Asian Economics, 12/3, 2001, pp. 309-329

Grossman, Gene M. and Elhanan Helpman. "Comparative Advantage and Long-Run Growth." In The American Economic Review, 80/4, 1990, pp. 796-815 
Haas, Hans Dieter and Simon-Martin Neumair. Internationale Wirtschaft. München: Oldenbourg, 2006

Harrod, Roy F. “An Essay in Dynamic Theory.” In The Economic Journal, 49/193, 1939, pp. 1433

Hess, Peter and Clark Ross. Economic Development: Theories, Evidence, and Policies. Fort Worth: Dryden Press, 1997

Huff, W.G. "The Developmental State, Government, and Singapore's Economic Development since 1960." In World Development, 23/8, 1995, pp. 1421-1438

Ichimura, Shinichi, William James, and Eric Ramstetter. "The Financial Crisis in East Asia." In Asia Pacific Journal of Economics and Business, 2/1, 1998, pp. 3-20

Johns, Richard A. International Trade Theories and the Evolving International Economy. London: Frances Pinter, 1985

Johnson, Chalmers A. MITI and the Japanese Miracle: The Growth of Industrial Policy, 19251975. Stanford: Stanford University Press, 1983

Kien, Nguyen Trung. "Gravity Model by Panel Data Approach: An Empirical Application with Implications for the ASEAN Free Trade Area." In ASEAN Economic Bulletin, 26/3, 2009, pp. 266-77

Kojima, Kiyoshi. "The Flying Geese Model of Asian Economic Development: Origin, Theoretical Extensions, and Regional Policy Implications.“ In Journal of Asian Economics, 11/4, 2000, pp. 375-401

Krugman, Paul R. and Maurice Obstfeld. Internationale Wirtschaft: Theorie und Politik der Außenwirtschaft. Eighth Edition. München: Pearson, 2009

Krugman, Paul R., Maurice Obstfeld, and Marc J. Melitz. International Economics: Theory \& Policy. Ninth Edition. Essex: Pearson, 2012

Letiche, John M. "Causes of the Financial and Economic Crisis in Southeast Asia and the Need for National, Regional, and IMF Structural Reforms.” In Journal of Asian Economics, 9/2, 1998, pp. 181-191

Lin, Tin-Chun. "The Role of Higher Education in Economic Development: An Empirical Study of Taiwan Case." In Journal of Asian Economics, 15/2, 2004, pp. 355-371

Linder, Staffan B. An Essay on Trade and Transformation. Stockholm: Almqvist \& Wiksell, 1961

Manzenreiter, Wolfram. "Jenseits von Japan: Staat und Wirtschaft in der industriellen Modernisierung Ostasiens.” In Ostasien im 20. Jahrhundert: Geschichte und Gesellschaft, edited by Sepp Linhart and Susanne Weigelin-Schwiedrzik. Wien: Promedia, 2007

Markusen, James R., James R. Melvin, William H. Kaempfer, and Keith E. Maskus. International Trade: Theory and Evidence. New York: McGraw-Hill, 1995

Münt, Gunnar. Dynamik von Innovation und Außenhandel: Entwicklung technologischer und wirtschaftlicher Spezialisierungsmuster. Heidelberg: Physica, 1996

Nafziger, Wayne E. Economic Development. Fifth Edition. New York: Cambridge University Press, 2012

Park, Yung Chul. "Development Lessons from Asia: The Role of Government in South Korea and Taiwan.” In The American Economic Review, 80/2, 1990, pp. 118-121

Patel, Surendra J. "The Economic Distance between Nations: Its Origin, Measurement and Outlook.” In The Economic Journal, 74, 1964, pp. 119-131

Pempel, T. J. "The Developmental Regime in a Changing World Economy." In The Developmental State, edited by Meredith Woo-Cummings. New York: Cornell University Press, 1999

Rivera-Batiz, Luis and Maria-A. Oliva. International Trade: Theory, Strategies, and Evidence. Oxford: Oxford Press, 2003 
Romer, Paul M. "Increasing Returns and Long-Run Growth.” In Journal of Political Economy, 94/5, 1986, pp. 1002-1037

Romer, Paul M. "Endogenous Technological Change.” In Journal of Political Economy, 98/5, Part 2, 1990, pp. 71-102

Rosenstein-Rodan, Paul N. "Problems of Industrialisation of Eastern and South-Eastern Europe." In The Economic Journal, 53/210-211, 1943, pp. 202-211

Rostow, Walt Whitman. "The Take-off into Self-sustained Growth.” In The Economic Journal, $66 / 261,1956$, pp. $25-48$

Rostow, Walt Whitman. The Stages of Economic Growth: A Non-communist Manifesto. Third Edition. Cambridge: Cambridge University Press, 1990

Rübel, Gerhard. Grundlagen der Realen Außenwirtschaft. München: Oldenbourg, 2004

Rybczynski, Tadeusz M. "Factor Endowment and Relative Commodity Prices." In Economics, 22/88, 1955, pp. 336-341

Samuelson, Paul A. "International Trade and the Equalisation of Factor Prices." In The Economic Journal, 58/230, 1948, pp. 163-184

Siebert, Horst. Außenwirtschaft. Seventh Edition. Stuttgart: Lucius \& Lucius, 2000

Solow, Robert M. "A Contribution to the Theory of Economic Growth." In The Quarterly Journal of Economics, 70/1, 1956, pp. 65-94

Stiglitz, Joseph E. "Some Lessons from the East Asian Miracle." In The World Bank Research Observer, 11/2, 1996, pp. 151-177

Stolper, Wolfgang F. and Paul A. Samuelson. "Protection and Real Wages." In The Review of Economic Studies, 9/1, 1941, pp. 58-73

Tinbergen, Jan and Hendricus C. Bos. Mathematical Models of Economic Growth. New York: McGraw-Hill, 1962

Todaro, Michael P. and Stephen Smith. Economic Development. Eighth Edition. Essex: Pearson, 2003

van Marrewijk, Charles. International Economics: Theory, Application, and Policy. Oxford: University Press, 2007

Vernon, Raymond. "International Investment and International Trade in the Product Cycle." In The Quarterly Journal of Economics, 80/2, 1966, pp. 190-207

World Bank. "World Development Indicators." 2013, Data website, http://data.worldbank.org/ data-catalog/world-development-indicators, accessed July 2013

World Bank. "World Development Indicators 2011.” 2011, Open Knowledge Repository website, https://openknowledge.worldbank.org/handle/10986/2315, accessed August 2013

World Trade Organisation. "10 benefits of the WTO trading system." 2008, http://www.wto.org/english/res_e/doload_e/10b_e.pdf, accessed September 2013

World Trade Organisation. "WTO Statistics Database." 2013, Statistics Database website, http://stat.wto.org/Home/WSDBHome.aspx?Language=E, accessed October 2013

Yamarik, Steven and Sucharita Ghosh. "A Sensitivity Analysis of the Gravity Model." In The International Trade Journal, 19/1, 2005, pp. 83-126

Zhang, Wei-Bin. International Trade Theory: Capital, Knowledge, Economic Structure, Money, and Prices over Time. Berlin and Heidelberg: Springer, 2008 